SH

222

$\mathrm{A}_{4} \mathrm{~A}_{5}$ 1905 


$$
\text { \% }
$$







\section{DEPARTMENT OF COMMERCE AND LABOR}

4. BUREAU OF FISHERIES

GBORGE M. BOWERS, Commísstoner

\section{THE \\ COMINERCIAL FISHERIES OF ALASKA \\ IN 1905}

Bureau of Fisheries Dociment No. 603

WASHINGTON

GOVERNMENT PRINTING OFFICE

1906 


\title{
THE COMMERCIAL FISHERIES OF ALASKA IN 1905
}

\author{
By JoHN N. СовB
}

Assistant Agent at the Salmon Fisheries of Alaska

Bureau of Fisheries Document No. 603 


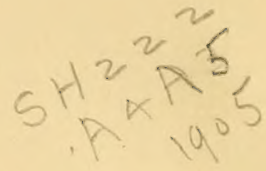

OCT 201906

D. OF D.

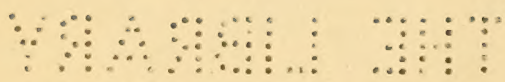

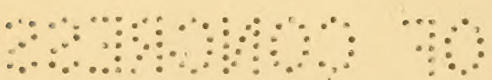




\section{CONTENTS.}

Page.

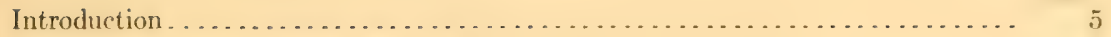

Importance of the Alaskan fisheries. . . . . . . . . . . .

The fishing grounds. . . . . . . . . . . . . . . . . . . . . . . . . . .

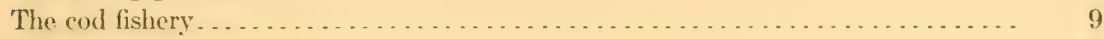

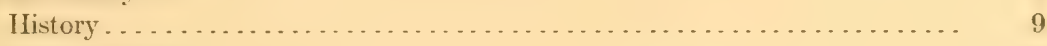

Fishing banks . . . . . . . . . . .

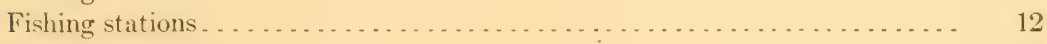

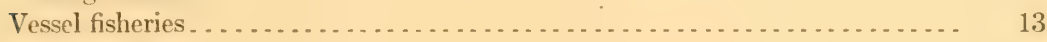

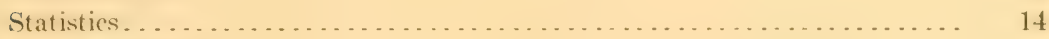

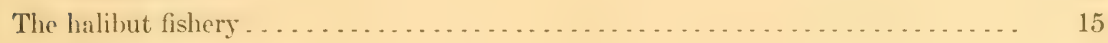

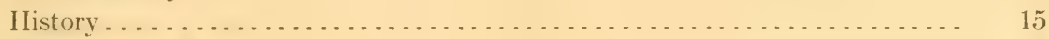

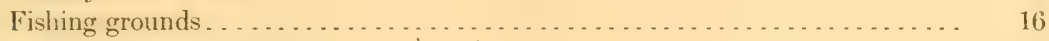

Methods of the fishery . . . . . .

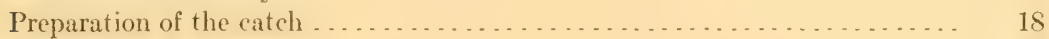

The herring fishery . . . . . . . . . . . . . . . . . . . . . . . . . . . . 20

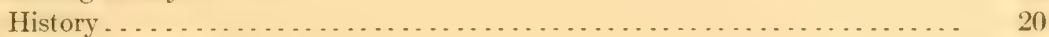

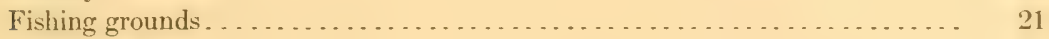

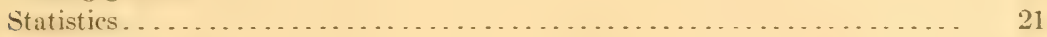

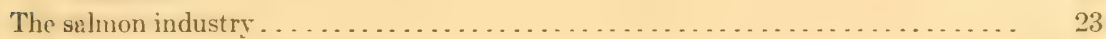

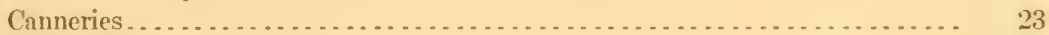

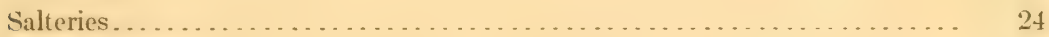

Freezing salmon . . . . . . . . . . . . . . . . . . . . . . . . . . . . 25

Hatcheries. . . . . . . . . . . . . . . . . . . . . . . . . . . 25

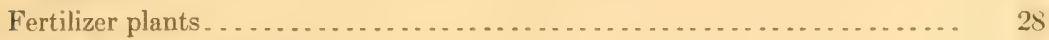

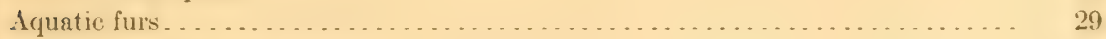

Miscellaneous aquatic animals . . . . . . . . . . . . . . . . . . . . . . . . . 33

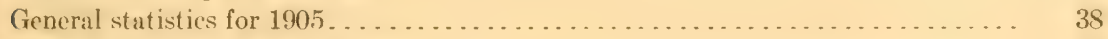

Other fishery resources of Alaska . . . . . . . . . . . . . . . . . . . . . 43

Fisheries carried on in Alaskan waters and credited to places outside of the district .. 45 



\title{
THE COMIMERCIAL FISHERIES OF ALASKA IN 1905.
}

\author{
By Joms N. CoвB, \\ Assistant Agent at the Salmon Fisheries of Alaska.
}

\section{INTRODUCTION.}

The salmon and seal fisheries of Alaska constitute such conspicuous features of the fishing industry in that region that published reports have to a great extent neglected the other aquatic resources, and no complete compilation of statistics has ever been made. The Tenth (1880) and Eleventh (1890) censuses covered the ground partially, but the census agents had to deal with all phases of Alaskan endeavor and their reports upon the commercial fisheries were consequently not so complete as could be desired. The salmon fishery was treated by them in considerable detail, and has been canrassed and reported upon very fully by the Burean of Fisheries." The seal fishery has been the subject of investigation and legislation recorded in many volumes published by the Treasury Department, and more recently in the reports of the Department of Commerce and Labor. No special canvass of the other fisheries, howerer, has heretofore been made, the information published at varying periods by the Bureau of Fisheries being such as could be gathered by its agents at San Francisco in connection with their canvass of the Pacific coast states.

The data presented in the following pages for the year 1905 are the result of the writer's personal canvass of a portion of the region and the collection of reports from various fishing firms and officials of the government in Alaskia. A history and recapitulation of results of the various fisheries is also given.

\section{IMPORTANCE OF THE ALASKAN FISHERIES.}

Long before the acquisition of Alaska was even dreant of by our statesmen its wealth in fishery products was known, by hearsay at least, to the hardy mariners of the Pacific coast, as well as to the

$a$ The salmon and salmon fisheries of Alaska. Report of the operations of the U.S. Fish Commission Steamer Albatross for the year cnding June 30, 1895, by Jefferson F. Mfoser. Bulletin U. S. Fish Commission 1898, vol. xvirr, 1899, p. 1-178, pl. 1-63, charts A and B. Idem, 1900 and 1901, Bulletin 1901, vol. xxI, 1902, p. 173-395 and 299*-101*, pl. i-xliv, pl. $A$ and charts $A, B$. 
whalers from New Bedford, Mass., and other Atlantic ports, who frequented the waters of the north Pacific and Arctic oceans. In the memorial to the President of the United States adopted by the legislature of Washington Territory in the winter of 1866 especial stress was laid upon the fishery resources of the territory and the need for an arrangement with Russia by which our fishing vessels would be enabled to resort to the Alaskan harbors for shelter and to procure fuel, water, and provisions. Even at that time our fishermen were engaged in cod fishing on the Alaskan banks, the first vessel having gone there in 1863, while our whalers had been working in Bering Sea and along the Arctic shore for years.

The treaty of cession between Russia and the United States was signed March 30, 1867, ratified by the Senate May 28, and proclaimed by the President June 20 of the same year. Formal and actual possession was taken on the 16th of the following October. Much doubt was expressed in this country as to the wisdom of paying so large a sum of money for such an apparently sterile region as Alaska, and it was feared that the expenditure would never be justified. Such calculations were much at fault, however. The United States has not only been more than reimbursed directly, but through the fisheries alone has been many times compensated for the financial outlay. The rental from the fur-seal islands has more than paid the initial cost of the distriet, and at the present time the tax derived from the salmon fishery amounts to about $\$ 90,000$ a year.

The following table shows, so far as it has been possible to secure reliable information, the quantity and value of fishery products secured in Alaskan waters from 1868 to 1905 (both inclusive). In some instances, where but rather fragmentary data could be obtained, estimatesbased upon the figuresin hand havebeen inserted for the missing years. The second column in the table shows the products in units as put on the market, but in the third column all have been reduced to pounds for convenience in comparison. The dates given indicate the number of years the fishery in question has been prosecuted. No account has been taken in this table of the very extensive intertribal commerce of the natives in fishery products, as there are no accurate data for this feature. 
Quantity and Value of the Fisiery Prodects of Alaska Mlarketed in Stated YeARs, 1868 to 1905.

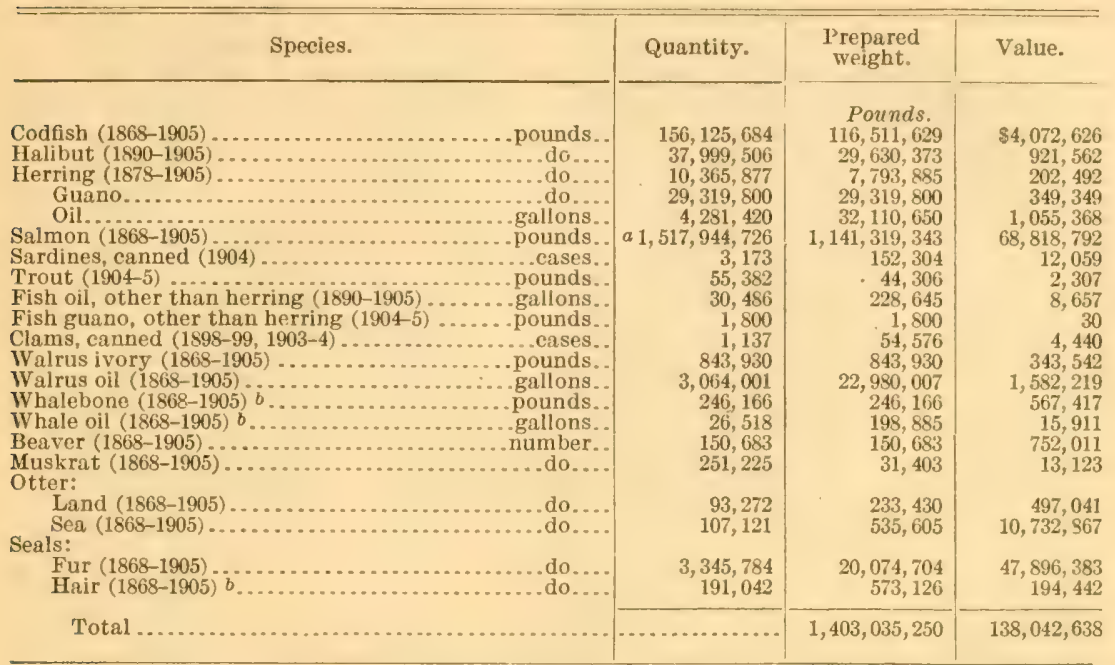

$a$ Includes $21,784,106$ cases of canned salmon, with an estimated value of $\$ 3$ per case.

$b$ Estimated from data covering a portion of the period.

THE FISHING GROUNDS.

The district of Alaska is enormous in extent, being equal to nearly one-sixth of the United States proper. The total length of mainland from southeast to northwest is about 1,150 miles, the greatest width is about 800 miles, and the area is about 590,000 square miles. Because of the thousands of islands scattered along the coast, or, as in the case of the Aleutian chain, extending out to sea hundreds of miles, the district has an exceedingly long coast line and one well adapted to fishing, owing to the many large and safe bays, the sheltered channels between the islands and the mainland, and the numerous rivers which debouch from the mainland. The Nushagak River is to-day one of the important fishing streams of the world.

Following is a list of the fishing banks of importance off the Alaskan coast and in adjacent foreign waters so far as they have been discovered and charted. Notwithstanding the extensive fishing in this region, there are doubtless many fishing banks still unknown. 


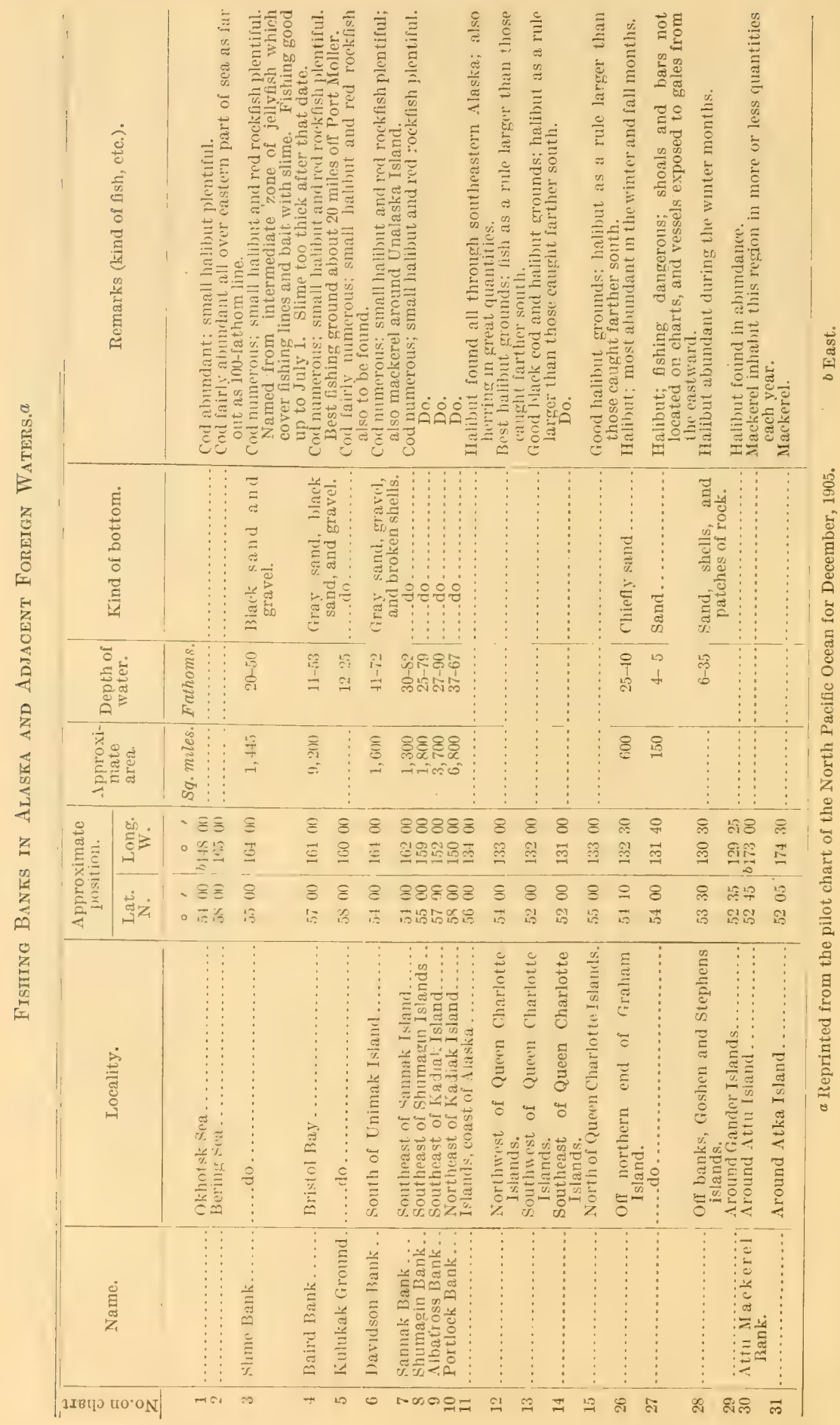




\section{THE COD FISHERY.}

HISTORY.

The presence of cod along the Alaskan coast has been known for many years. The first mention was made by a Russian natvigat or in 1765, who reported "cod, perch, pilchards, smelts" as being found around the Fox Islands. Other navigators and explorers who reported the presence of cod were Cook (1786), Portlock (1757), Meares, Billings (1792), Langsdorf (1804), Sutke, and Sir George Simpson (1841), all of whom speak of it as being a very common fish. But little use was made of it, however, owing to the abundince of silmon. Early in the sixties Ameriean vessels from S.n Fruncisco discovered and fished on the cod banks in the Okhotsk Sea, the first American vessel to visit $A$ laskan waters apparently being the schooner Alert, which made a voyage to Bristol B: $y$ in 1863 . She seeured but 9 tons of cod, however, the captain's principal incentive to make the trip probably being to trade with the natives.

On March 27, 1865, Captain Matthew Turner, with the schooner Porpoise ( 45 tons), of San Franciseo, sailed for $\mathrm{Al}$ s skil, and urrived at the Shumagin Islands May 1. The vessel returned on July 7 with 30 tons of cod, having left the banks early in order to get bick to Sam Franciseo before the Okhotsk fleet. This wais the first fare erer taken from around the Shumagins, one of the best grounds in $11 ;$ ska. The Simeonoff Bank was discovered by the Minnie S. Athines in 1867 .

The acquisition of Alaska by the United States in $1 \$ 67$ proyed a boon to the codfishermen, as it secured the Americans, who did : ll the fishing, from any interference on the part of the owners of 11 skia. This is well shown by the fact that while the fleet in 1567 numbered 3 vessels, with a catch of 136,000 fish, the flect of 1868 comprised $1+4$ vessels, which made a catch of 608,000 fish.

It was early discovered that the time required for the vessis to reach the banks from San Francisco and return was wasted, and in 1876 T. W. McCollam \& Co., which firm later merged into the Inion Fish Company, one of the first to engage in the fishery on a li.rge scale, established a permanent fishing station at Pirate Cove on Popoff Isl. nd, one of the Shumagin group. From this station fishermen in dories went out each day, returning in the evening with the di.y's catch. In this way fishing could be carried on the year through, and the plan was followed as time went on until now nearly : ll of the companies operating ressels in Alaska have one or more stations. Certain ressels are employed in currying supplies to these stations from the home ports and in taking back the cod caught.

The first Alaskan ressel in the fishery was one owned by cuptrin Haley, of Trangell, who in 1879 fished on the Hoochenoo I3:ank in Frederick Sound, and sold his eatch in Wrangell for $\$ 1(0)$ per tom. The regular Bering Sea fishery was inaugurated by the Tropic Bird in 1883.

$7115-06-2$ 
For years the fishery was followed by San Francisco firms only, but in 1891 Capt. J. A. Matheson, of Anacortes, Wash., brought the schooner Lizzie Colby (142 tons) around Cape Horn and sent her to Bering Sea, and he has continued in the fishery there ever since. The Western Canadian Fish Company, of Vancouver, British Columbia, sent a vessel to Bering Sea in 1903 and continued the venture until 1905, when the company failed. The Robinson Fisheries Company, of Anacortes, and the Seattle and Alaska Fish Company, of Seattle, sent their first vessels to Alaska in 1904. In 1905 King \& Wing, of Seattle, and the Blom Codfish Company, of Tacoma, entered the fishery.

\section{FISHING BANKS.}

While most of the fishing banks were known to the fishermen in a general way, it remained for the steamer Albatross to survey and plat them during her investigations in Aliskan waters from 1888 to $1892{ }^{a}$

Following is a summarized description of the banks, first those in Bering Sea :

Slime Bank.-This is the first of the larger fishing grounds reached after entering Bering Sea through Unimak Pass. The bank begins directly off the Northwest Cape of Unimak Island, is elongate in shape, and follows approximately the trend of the adjacent coast to within a few miles of Amak Island, its inner margin lying only a short distance off the land. It is about 85 miles in length and 17 miles in average width, broadening somewhat at the eastern end; its total area is estimated at about 1,445 square miles, and the depths range from 20 to 50 fathoms. The bank derives its name from the presence of immense numbers of a large jelly-fish, measuring from 6 to 18 inches across the disk, and provided with long, slender tentacles having great stinging powers. These animals are not found upon the surface, but seem to occupy an intermediate zone toward the bottom, where at times they occasion much annoyance to the fishermen by becoming entangled with the fishing gear.

Baird or Moller Bank. - This is the largest bank yet discovered on the Alaskan coast. It commences a few miles east of Amak Island and extends northeastward off the northern side of the Alaska penmsula to the vicinity of Cape Chichago at the mouth of Ugaguk River, a distance of about 230 miles. It has an average width of about 40 miles and an extreme width of 58 miles, its total area being estimated at about 9,200 square miles. The boundaries have not been thoroughly established, and possibly comprise a greater area than is stated above.

In Kulukak Bay are numerous spots where cod are found, but none are of sufficient size to entitle them to be called banks.

a Fishery investigations of the steamer Albatross from July 1, 1888, to July 1, 1892, by Richard Rathbun. Bull. U. S. Fish Com., 1892, p. 127-201. 
('ravel Bank--Fishermen sometimes visit this small bank, which lies about 16 miles southwest from the southern end of IIagemeister Island, and they state that large cod are abundant there. The depths are from 16 to 20 fathoms.

The Albatross investigations were not carried north of Cape Newenham. According to Petroff, in the Tenth Census, corlfish have been reported at a few points along the Aretic coast, but no banks have been located, rery likely because no eflort has been made to finid them.

Cnalasha Ilarbor, etr.-Fisherme: have reported cod banks in the neighborhood of Unalaska IIarbor, but the investigations of the $1 / b a-$ tross do not seem to sustain the claim. The cod fishing directly off Chernoffsky Bay is said to be excellent.

On the southern side of the Alaskan peninsula are the following banks:

Davidson Bank.--This bank was discovered about 1.570 by Prof. George Davidson, of the United States Coast and Geodetic Survey, after whom it is named. It lies south of Unimak Island, and extends westward from the neighborhood of the Sannak Islands to about the longitude of the southem entrance to Unimak Pass (about longitude $164^{\circ} 40^{\prime} \mathrm{W}$.). Its eastern end is continuous with the shoal water surounding the Samnak Islands; its area was estimated at about 1,600 square miles.

Sunnak Bank.--To the east and southeast of the islands of the same name lies Sannak Bank, somewhat elongate in shape and trending in a reneral way ilortheast and southwest. It is estimated to have an area of about 1,300 square miles.

The region between Samnak Bank and the Shumagin Islands was only partly surveyed, but about 1,800 square miles fairly well adapted to fishing were covered.

Shumagin Banki.--Lying to the south and southeast of the Shumagin Islands, with its outer margin following approximately the trend of the coast line formed by the adjacent islands, is Shumagin Bank, which has been traced westward to about longitude $159^{\circ} 52^{\prime} \mathrm{WT}^{\circ}$, but probably extends farther in that direction; east of the shumarin Islands it reaches north to the latitude of Big Koniuji Island. Its wirth inside of the 100 fathom curve raries from 15 to 35 miles, while its area has been estimated at about 1,800 square miles.

From the Shumagin Islands to Kadiak Island the area was only partially surveyed, but the work done indicated the existence of sereral fishing banks.

Allatmss Bank,-Off the southeastern side of Kadiak Island is Albatross Bank, extenting the entire length of that island as well ats in front of the Trinity Islands. At the eastern end it is practically continuous with Portock Bank. Along some portions of the eanst. as in the neighborhood of Sitkalidak Island, the bank is separated 
from the land by comparatively deep water, while in other places shoal water intervenes. The 100 -fathom curve is distant 2.5 to 45 miles from the land, inside of which limit there is an estimated area of 3,700 square miles.

Portlock Bank.-This bank extends northeastward from Kadiak Island in the direction of Niddleton Island, a distance of about 120 miles, and is irregular in shape. It is the largest single bank south of the Alaska peninsula, its area inside of the 100-fathom curve being about 6,800 square miles.

The Albatross continued her investigations as far to the eastward as Middleton Island, but no banks were found.

Codfish have been reported in the western part of the Gulf of Alaska and in the waters of Southeast Alaska, but nowhere do there seem to be any banks which it would be profitable to work with vessels especially devoted to this fishery.

\section{FISHING STATIONS.}

At the present time nearly one-half of the codfish taken in Alaska are caught by fishermen from the numerous stations scattered along the Alaska peninsula and the islands adjacent thereto on the southern side. The business of fishing from stations has fluctuated considerably from year to year. The year 1892 was the banner year, $2,208,035$ pounds of fish being taken by fishermen from stations, to $1,7+2,155$ pounds secured by the fishing vessels. The stations soon after began to be abandoned, and for a few years but few were in operation. Of late years, however, they have regained their popularity, and it is probably only a question of a few years until all of the corl fishing outside of Bering Sea will be carried on from the shore stations. During the season of 1905 the following stations were operated.

Iinion Fish Company.-Pirate Cove, Popoff Island; Northwest Harbor, Big Koniuji Island; Sanborn Harbor, Werge Cape, and Eagle Harbor, on Nagai Island; Pavlof Harbor and Johnsons IIarbor, on Sannak Island.

Alaska Codfish Company.--Mofietts Cove and Companys IIarbor, on Samnak Island; Dora Harbor, on Alaska peninisula; and Winchester and Banenhoff, on Unga Island.

Seattle-Alaska Fish Company.--Squaw I Iarbor, on Uniga Island.

Aleutian Live Stock and IFining Company.-Lost IIarbor, Akun Island.

This year (1906) the Pacific States Trading Company is erecting two stations on the Shumagin group.

Nearly all of these stations are open the whole year round, the fishermen going out in their dories each day when the weather is favorable, and but rarely having to go more than 5 miles from any of 
the stations before good fishing grounds are reached. There is usually one man to a boat and trawl lines are quite generally employed, although a few hand lines are used. In good weather the trawls are hauled two or three times a day, but the fish are not dressed until the last haul for the day has been made.

Whein not out in the dories the fisherman's time is his own. He is paid from \$25 to $\$ 30$ per thousand fish of 26 or more inches in length, and he must dress and salt them. The wage is less for fish under 26 inches. The station owner furnishes the men with boats, lodging, food, and fuel, the fishermen providing only the fishing gear. The catch is kench cured, and later shipped away to San Francisco and Puget Sound ports on the transporting vessels, where the final curing is accomplished.

\section{VESSEL FISHERIES.}

Nearly all of the fleet fish in Bering Sea, where the banks are too far from the shore for shore fishing, or where harbors are not available.

With the exception of three ressels which use trawl lines, all fishing is with hand lines from dories, one man to a boat. The fishermen do not dress and salt their own catch, as is the custom on the Atlantic coast, but each vessel carries a dressing gang, varying with the number of fishermen, and a splitter and salter, who do this work. The captain usually receives about $\$ 125$ per month; the cook, $\$ 75$; the first mate, \$10; the second mate, \$35; the fishermen, \$2.5 and $\$ 27$ per 1,000 fish, according to the size; dressing gang, \$25 per month each, and the splitter and salter, 875 per month. All hands get board also. When not engaged in their regular work the dressing gang usually fish over the side of the vessel and are paid $\$ 25$ per 1,000 for all fish so caught. A vessel usually makes but one trip to the banks, leaving in the spring and returning in the late summer or early fall, but sometimes if she meets with good luck on her first trip she will make a second one. The fish are salted in bulk in the hold of the ressel, about 1 ton of salt being required for 1,000 fish, and the balance of the curing is done at the ressel's home port. The crew have nothing to do with unloading the vessel, that work being done by the employees at the home station.

The principal bait used in both shore and ressel fisheries is halibut, seulpins; and cuttlefish. In hand-lining only a small quantity of bait is brought on the ressels, because after the first few hours' fishing the shack fish brought up will suffice for baiting. For trawling, however, more bait is required, and the stations generally gather it at various places and furnish it to the fishermen either fresh or salted, as may be most convenient. 
Certain of the vessels do nothing but ply between the stations and the home ports, bringing up supplies and carrying back the salted fish. These vessels make from three to four trips a year.

But few of the tongues, sounds, and livers of the cod are saved, either in shore or vessel fisheries.

\section{STATISTICS.}

The table below shows, by years, the condition of the fishery since its inception, in 1863. An interesting feature of this table is that while the average cured weight of a codfish was slightly over 23 pounds in 1868 , in 1905 the average had risen to 4 pounds. This is due to the fact that the vessels now work largely on the outer banks, where the fish are larger than on the banks close to shore, which were the ones from which most of the fish came in the early days of the fishery. For some years the fishery was almost stationary, owing to the lack of an expanding market for Pacific cod, but during the past five years the demand has been quite heary and has resulted in a considerable increase in the fleet and a corresponding increase in the eatch.

Vessels Engaged in Cod Fishing in Alaskan Waters, Together witi the Quantity and Value of Cod Taken, 1863 to 1905.

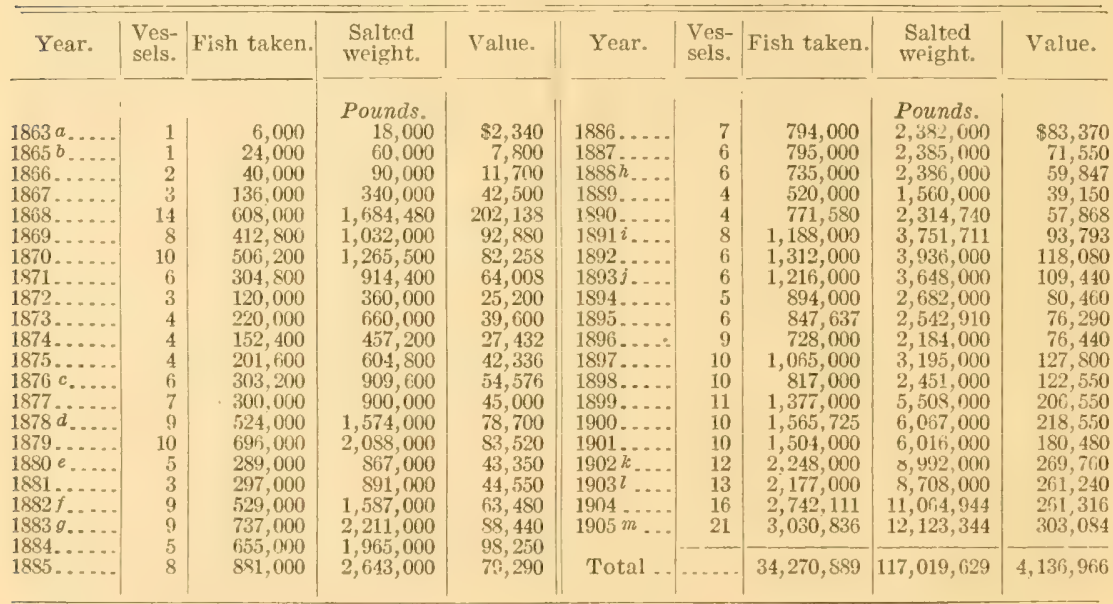

a First vessel to fish for cod in Bristol Bay.

$b$ Beginning of the Shumagin Islands fishing.

$c$ Shore fishing station established at Pirate Cove.

d One vessel lost.

$e$ Schooner Nagay lost in the spring.

f Schooners General Miller and H. L. Tiernan lost.

$g$ Schooner IVild Gazelle lost.

$h$ Schooner Isabel lost with 14 men.

$i$ Schooner Dashing Wave lost.

1 Schooner John Hancock lost.

$k$ Schooner Anna lost with full cargo.

$l$ Includes schooner Blakeley, of Vancouver, British Columbia; 2 Seattle (Wash.) firms began this year: schooner Mary and Ida lost with 78,000 fish.

$m$ Schooner Pearl lost with 30 men; schooner Nellie Coleman lost with all on board. 


\section{THE·HALIBUT FISHERY.}

\section{HISTORY.}

The halibut is now one of the most extensively sought species in our commercial fisheries. For many years the Atlantic banks amply supplied the constantly growing demand, but ultimately these began to show the effects of the heavy drain upon them, and then the important eastern fishing companies began to turn their attention to the Pacific, where large banks had been reported.

The inception of the industry on the Pacific coast may be said to have been about twenty-one years ago, when several schooners from Port Townsend, Wash., began to fish off Cape Flattery, but their catches were small. $\Lambda$ few years later an eastern fish firm established a branch at Tacoma, which caused a transfer of the business almost entirely to that city. In the meantime, a demand had been created in the West for Pacific halibut, and in a few years more the fish houses of Seattle began to compete for the fish caught by the schooners, with the result that the trade shifted to that city, and the bulk of the schooner trade has been done there ever since. At the present time the International Fisheries Company, of Tacoma, a connection of an eastern house, handles the bulk of the steamer trade on the American side, while the New England Fish Company, of Vancouver, British Columbia, handles the bulk of the steamer trade on the Canadian side. The latter company, however, is an American corporation, with American-built vessels, and nearly all of its catch enters this country in bond free of duty. Both companies have special arrangements with the transcontinental lines by which their fish, fresh in refrigerator cars, are rushed through by passenger service, thus enabling the companies to place the fish on the Boston and Gloucester markets in from six to seven days after it is landed on the const.

The New England Fish Company was the first to employ steamers in the fishery, beginning in 1897 . At present it operates three steamers, while the Tacoma company has four steamers cmployed in fishing and transporting. Within the last year several steamers and power boats have been fitted out at Seattle to engage in the industry.

It was about 1895 when the southeast Alaska banks began to be resorted to by Seattle schooners in the winter, it not being possible to do anything on the Cape Flattery banks at that season of the year, and the British Columbia banks being closed to them. Most of the vessels fished around Dixons Entrance, while others worked in Chatham Strait and Frederick Sound, the latter making their headquarters in Wrangell Narrows and shipping the fish to Puget Sound ports on the regular steamers. The fishing was quite desultory, how- 
ever, until 1899, when the Icy Strait Packing Company built a salmon cannery and a wharf at Petersburg, near the upper end of Wrangell Narrows, and arranged with the steamship companies to make regular calls for freight. From that time on the business rapidly concentrated at Petersburg, until now nearly all of the ressels make it their headquarters.

Since then a great development of the Alaskan halibut fisheries has occurred. In addition to the Seattle fleet, which comes up each winter to remain during the season, a few Alaskan sail and power vessels have entered the fishery. A considerable part of the business, however, is conducted on entirely different lines. A company or individual builds its plant in some place convenient to the fisheries and engages crews to go out in dories from day to day. Some have one central station and a number of subsidiary stations and employ a steamer to carry supplies from the former to the latter and bring back the fish caught. The principal halibut stations are Tee Harbor, Taku Harbor, Pleasant Bay, Wrangell Narrows, Ketchikan, Kake, Hoonah Village, Juneau, Fanshaw, Windom, and Farragut bays. At Tee Harbor and Taku Harbor large cold-storage plants are in operation in which the fish are frozen for shipment.

In addition to the wharf at Petersburg there were located in Wrangell Narrows in 1905 three large scows, each capable of taking care of from 200 to 400 boxes of halibut at a time. The schooners find it much easier to come alongside and discharge on these scows than on the wharf, while the steamer has very little difficulty in transferring the boxes from the scow to its hold. The scows are resorted to almost exclusively by the schooners and other sailing vessels from Seattle. Most of the steamers and power boats that fish in Alaskan waters in winter return to their home port to unload as soon as a fare has been secured. They usually make about two trips a month to the banks.

\section{FISHING GROUNDS.}

In the Pacific the halibut ranges from Bering Sea on the north, as far as present knowledge extends, to San Francisco and the Farallones on the south. According to the observations of Dr. T. H. Bean, the center of abundance is in the Gulf of Alaska, particularly off Kadiak and the Shumagin islands. Outside of Alaska the principal bank near American territory is found off Cape Flattery, in the mouth of the Straits of Fuca, in the state of Washington. Practically the entire catch by American vessels during the summer is made on this bank. In the winter months the supply comes entirely from scattering banks in southeastern Alaska, or from banks on the British Columbia coast outside the three-mile limit. 
Of the former banks, Mr. A. B. Alexander ${ }^{a}$, formerly fishery expert of the steamer Albatross, writes as follows:

Across Dixon Entrance, on the south side of Prince of Wales Island, in the vicinity of Nicholas Bay and Cape Chacon, a few schooners have taken good fares. Here, as at Capo Scott, the ground is made up of small "spots," which can only be located by landmarks. Only a few vessels can fish on this ground; it is said that even a small fleet would soon exhaust the ground, not permanently, but for some weeks. The Indians of this locality catch halibut here in considerable numbers, and from these people the white fishermen soon learn the best places.

* $\quad * \quad * \quad * \quad * \quad * \quad * \quad * \quad * \quad *$

Halibut on the northern banks are sometimes very erratic; in places where they are numerous one day few will be found the next. It frequently happens that a vessel will have good success for several days, and in a few hours' time fish will become so scarce that it is useless to remain longer on the ground. It is thought the fish are traveling in schools from one bank to another.

On all grounds halibut are more plentiful in winter than in summer and are searcer in June than at any other time of the year. At this season they scatter all over.

During the salmon-canning season (June to November) many halibut are to be seen near the canneries, where they feed on the salmon offal thrown overboard.

No effort has yet been made to fish the large banks in central and western Alaska, owing to the distance from markets and the poor shipping facilities, but ultimately these will furnish the bulk of the product.

Very important grounds are located ofl the Queen Charlotte Islands and along the coast of British Columbia, but most of these are barred to American fishermen because they are within the three-mile limit.

It is barely possible that more extensive investigation would reveal the presence in southeast Alaska of large banks similar to those of the British Columbia coast.

\section{METHODS OF THE FISHERY.}

The method of catching halibut is almost the same as on the Atlantic coast. When the grounds are reached, the vessel scatters its dories around in favorable spots and then lies to for a while. There are generally two men to a dory. First the buoy is launched and the buoy line thrown out, this line being usually about 150 feet in length with an anchor attached to the end. The trawl lines in the vessel fisheries are generally about 1,800 feet in length, and usually three are joined together so as to make one continuous line. The gangings are about 5 feet long, are attached to the ground line, and are placed about 15 feet apart. They have the hooks and bait (usually herring) attached, and are placed so as to rest on the bottom.

a Notes on the halibut fishery of the northwest. eoast in 1S(15, by A. B. Alexander. Bull. U: S. Fish Com., vol. xvir, 1897 (1898), p. 141-144.

$7115-06-3$ 
As soon as the buoy-line anchor has reached the bottom, the trawl is thrown from the side of the dory, and considerable skill is then necessary in order to place the trawl so that it will cover as much ground as possible and at the same time not get tangled up and crossed. In lifting the trawl the buoy line, with anchor, is taken in first and then the trawl. Sometimes a hurdy-gurdy (small windlass) is used in this work in order to facilitate matters. The fish are hauled to the surface, hit on the head with a club, unhooked, and thrown into the dory. Various other species besides the halibut are secured, but nearly all are thrown away. One of the greatest pests in the halibut fisheries of the Pacific, as well as of the Atlantic, is the dogfish, many of which get caught on the lines. They range in weight from 8 to 20 pounds, and are utterly valueless to the fishermen.

In the dory fishing from the regular Alaska shore stations the fishermen generally use 6 lines of about 150 feet each to each skate of gear, and 2 skates are used to a dory. Generally one skate is set out in the morning and the other in the afternoon. As a general thing the lines are set from one and a half to two hours and then taken up in the manner described above.

Hand lines, occasionally employed by the white fishermen, are nearly always used by the natives, who attach hooks of a very primitive but quite effective shape.

On the steamers the fishermen are generally paid from 20 to 25 cents apiece for the fish caught, the owner of the vessel furnishing everything necessary for carrying on the fishery, including provisions. The fisherman receives the same price for a small fish as for a large one. On the schooners the fishing is generally done on shares, the vessel as a usual thing taking one-third and the crew the balance. Under this plan all the living expenses are taken from the returns before the division is made. The boat furnishes the gear.

PREPARATION OF THE CATCH.

In shipping fresh fish the entrails are removed and the fish packed in ice in boxes holding about 500 pounds net weight. The ice used is gathered from the neighboring glaciers, and is in the best form for use if ground in a mill made for the purpose, but often it is merely broken into fine lumps with a club.

The large halibut and those secured where the opportunities for shipping are infrequent are fletched. In this process the two sides are taken off in two complete pieces, which are then put into bins and buried in salt so that the brine will run off. Here they remain from eight to ten days and are then repacked, being resalted if necessary, and allowed to remain until cured, when they are packed in boxes for shipment. A considerable part of this work is done during the summer months when it is not profitable to ship halibut fresh. 
Large quantities of halibut are prepared each year by the Indians for food in the winter season. The fish are cut in strips, partially dried in the open air, and then suspended in the smoke from the fires generally built on the floor in the center of most of the Indian houses.

The possibility of developing an important and profitable industry in the canning of halibut has often been canvassed in Alaska, but the difficulty of interesting capital in an untried industry, when the profits of salmon canning have been so sure for many years, has usually been too great for the promoters. The first halibut canned in Alaska were put up at the Klawak cannery in 1878 , when 200 or 300 cases of 2 -pound cans ( 2 dozen cans in a case) were packed. This venture was continued for a few seasons, not more than 300 cases of 2-pound cans being packed in any one season, and then abandoned owing to the lack of a market for the product. In the summer of 1904 the Alaska Fish and Halibut Company opened a small cannery on Wrangell Narrows, just above Tonka, and put up an experimental pack of 41 cases of 1 -pound flats ( 48 cans to the case). Some of the cases were shipped to Boston and other eastern points, and the balance distributed on the Pacific coast, where they have met with a very good reception. If the results of the experiment justify it, the company expects to put up a one-line cannery to be devoted exclusively to the packing of halibut. During the winter of 1904-5 the Juneau Packing Company, of Juneau, put up 36 1-pound cans as an experiment, and expects to enter into the business on a large scale should the goods meet with a favorable reception. The writer had an opportunity to see and taste these goods, and found them both pleasant to the eye and agreeable to the taste. The West Point Packing Company, at Petersburg, expected to put up a small pack in the winter of 1905-6.

One very favorable feature of this industry, if it be established, is that it can be prosecuted at all seasons of the year. Salmon canneries could be utilized when not engaged in the packing of salmon, thus saving the initial cost of a plant put up especially for halibut. The salmon canning season begins in June usually, and, with the exception of a few plants, closés by October. Halibut are most abundant during the winter months, the very season when the salmon canneries are shut down.

The Juneau Packing Company, of Juneau, put up a large smokehouse during 1904, and is now engaged in the smoking of halibut, herring, and salmon. The greater part of its prepared product is shipped to Puget Sound ports. 
THE HERRING FISHERY.

HISTORY.

As early as 1878 persons in Wrangell engaged in the business of catching herring, from which they extracted the oil, in addition to salting and drying the fish. In 1880 the Western Fur and Trading Company, at their St. Paul (Kadiak Island) fishery, put up 500 boxes (30 pounds each) of smoked herring and 25 one-quarter barrels and 100 kits of salted herring.

The fertilizer plant at Killisnoo, on the island of Kenasnow, close to the western shore of Admiralty Island, owned and operated by the Alaska Oil and Guano Company, is the largest and oldest concern engaged in the herring fisheries. In 1882 the Northwest Trading Company, the predecessor of the present company, established at Killisnoo a small plant for extracting oil. As it proved successful it was gradually enlarged, and in 1884 the plant for the manufacture of guano was installed. The works at present are quite extensive, with commodious storehouses and a fine wharf. The common barrels used are made on the premises by machinery. As the fish while breeding are very poor and furnish no oil, the factory does not begin to operate until June, by which time the fish are feeding again and have commenced to fatten. In June it is estimated that one barrel of fish will furnish about half a gallon of oil; from this time the quantity obtained increases, until in the early part of September one barrel of fish produces about $3 \frac{1}{2}$ gallons of oil. It then begins to decrease until in December a barrel of fish will produce about 2 gallons of oil. The factory is generally operated from June to December. The season is frequently shorter, however; in 1905 it ran from June to October. Three steamers are employed and the fish are taken by means of purse seines. A few herring are salted each season, also.

During the season of 1905 the Alaska Fish and Development Company, of Pleasant Bay, on Glass Peninsula, installed a fertilizer plant aboard a large hulk anchored in the bay, but they were unable to get it in readiness to operate before the season closed. They put up a considerable quantity of salted herring, however. In 1904 this company operated a trap net for herring in the bay, but it was not set in 1905.

From 1899 on, various companies and individuals put up salted herring at points along the coast south of the Aleutian chain. The fishing in Norton Sound and on the Yukon River is done by natives with seines, and the fish caught are either consumed locally or exchanged with the interior tribes for other articles.

On June 15, 1904, the sardine cannery of the Juneau Packing Company was opened at Juneau, and during the balance of the year put 
up 3,173 cases of one-quarter oil and three-quarter's mustard sardines, valued at $\$ 12,059$. These were prepared from young herring. None were packed in 1905, owing to inability to compete with the excessively low prices quoted for easter: sardiies. As the prices of the latter have gone up to a normal figure again, it is probable that it will now be profitable to operate the cannery. The company also put up smoked and salted herring in addition to other fishes.

There is room for a very great development of the herring industry. For many years salmon absorbed all the attention and capital, but since the slump in profits in the latter busi zess during the last four years more attention has been directed to herring.

\section{FISHING GROUNDS.}

Herring are found in abundance at certain seasons of the year at many places on the Alaskan coast south of Bering Straits. They are rather erratic in their movements, however, being in one place especially abundant one year and totally absent the next, possibly returning again after several seasons in greater numbers than before. In southeast Alaska the herring arrive in April for the purpose of breeding, and deposit their eggs in countless numbers in the sea grass and rockweed near shore and on boughs of trees along the beaches near low-water mark. For many years the inlet at Kootznahoo, on Chatham Strait, was the favorite resort for herring, but they are much less abundant now, owing, it is claimed, to the constant fishing for them with purse seines, which breaks up the schools and drives them away. The northern shore of Kuiu Island and Gastineau Channel are also favorite spots, although the fish have been rather scarce in the latter place the last two seasons. They are quite abundant in Yakutat Bay, while Seldovia or Herring Bay, just inside the mouth of Cook Inlet, is a famous resort for them, immense schools making their appearance here each spring and autumn. About the middle of August large schools usually appear in the vicinity of Kadiak Island, and Captains Harbor, Unalaska Island, is frequented at certain seasons by large schools of exceedingly fat herring. Herring usually begin to arrive in the Yukon River from the 5th to the 20th of June. The run in Norton Sound is of very short duration, the fishing lasting only a fortnight, but the schools are said to be enormously large.

\section{STATISTICS.}

The table on page 22 shows the condition of the herring fishery from 1878, the first year for which reliable data could be secured. This table is not complete by any means, as salteries frequently spring up and are gone in a season, leaving no trace behind as to what they did. 
Extent of the Herring Fisheries of Alaska, 1878 to 1905.

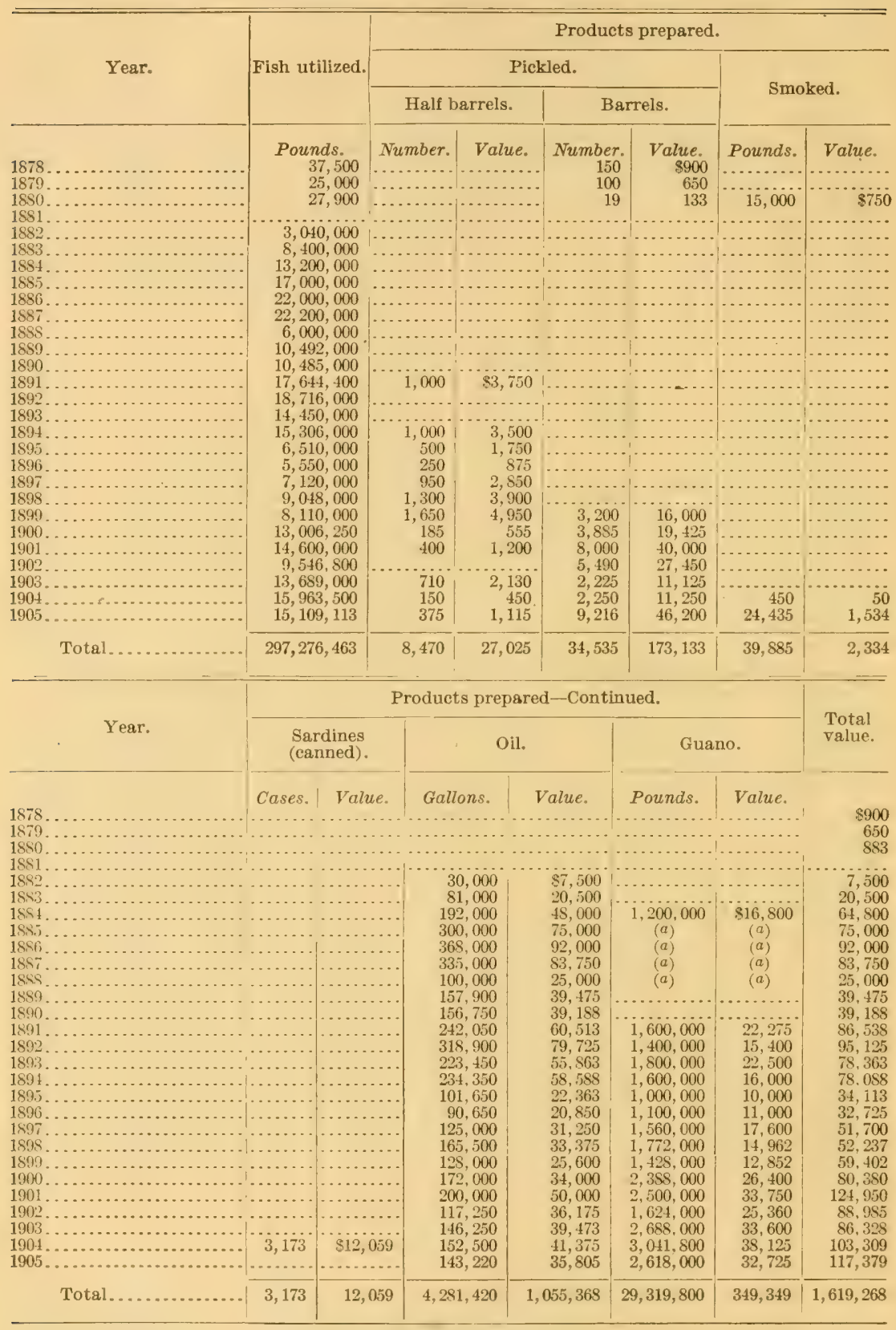




\section{THE SALMON INDUSTRY.a}

\section{OANNERIES.}

The first two canneries in Alaska were built in the spring of $1878-$ one at the Redoubt, Old Sitka, and the other at Klawak, both in Southeast Alaska. The latter was built by the North Pacific Trading and Packing Company, which still operates it. In Central Alaska the first cannery was built in 1882 at Karluk. The first in Western Alaska (Bristol Bay region) was constructed on the Nushagak River in 1884. By 1889 there were 37 canneries in operation, with a total output of 719,196 cases, a flood of canned salmon which was too much for the markets, so that by 1892 the number of canneries had fallen to 15 , with an output of 474,717 cases. From this time on there was a gradual increase until 1902, when there were 64 establishments in operation, packing $2,545,298$ cases; but the low prices prevailing during the last few years, owing to excessive competition, again reduced the number very materially, and in 1905 there were but 47 canneries, which put up $1, \$ 94,516$ cases. The table below shows by sections and years the number of camneries operated and the pack. It has been found impossible to give the value of the pack, owing to the wide fluctuations in price and the fact that establishments frequently held their pack for several seasons before disposing of it.

Pack of Canned Salmon in Alaska, 1878 to 1905.

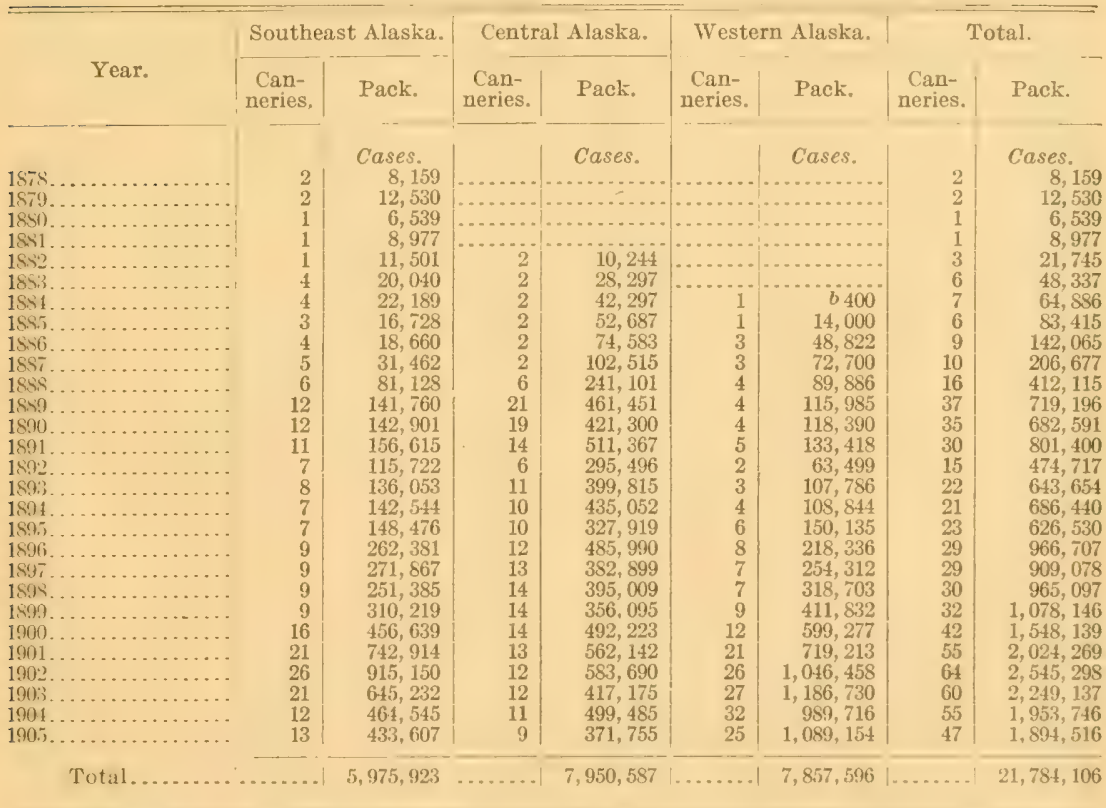

a No effort is made to give a detailed history of the fishery or of the methods followed, as these have been treated of, quite at length. in the publications of the Bureau and in the yearly reports of the agents appointed by the government to see that the salmon law is enforced.

b Experimental pack. 


\section{SALTERIES.}

The oldest Alaska salmon saltery now in existence is that established by Baronovich, a Greeis or Slav, who had married the daughter of Sliowl, one of the old-time chiefs of the Kasaans, and received from him the fishery on Karta Bay now known as Baronovich's Fishery. The saltery is operated only occasionally now.

The table below shows the pack of salted salmon since 1868. The salt salmon trade was so overshadowed by its giant brother, the canned trade, that it is frequently lost sight of or swallowed up in the latter. As a result it has been an exceedingly difficult matter to secure accurate data, and it is probable that a considerable part of the trade, especially in the earlier years, has been overlooked. The preparing of dry-salted dog salmon for market was first attempted in 1899. In 1900 a number of persons rushed into the business and overstocked the market, with the result that the industry became unprofitable and nothing was attempted for two seasons, when the demands of the Japanese trade for a cheap dry-salted fish caused a revival of the business. From 225 to $250 \mathrm{dog}$ salmon are required to make a prepared ton of dry salted. These are packed in boxes holding about 560 pounds net. Fifteen pounds of salt are required to a box of fish, while the box itself weighs 95 pounds.

Pack of Salted Salmon in Alaska, 1868 to 1905.

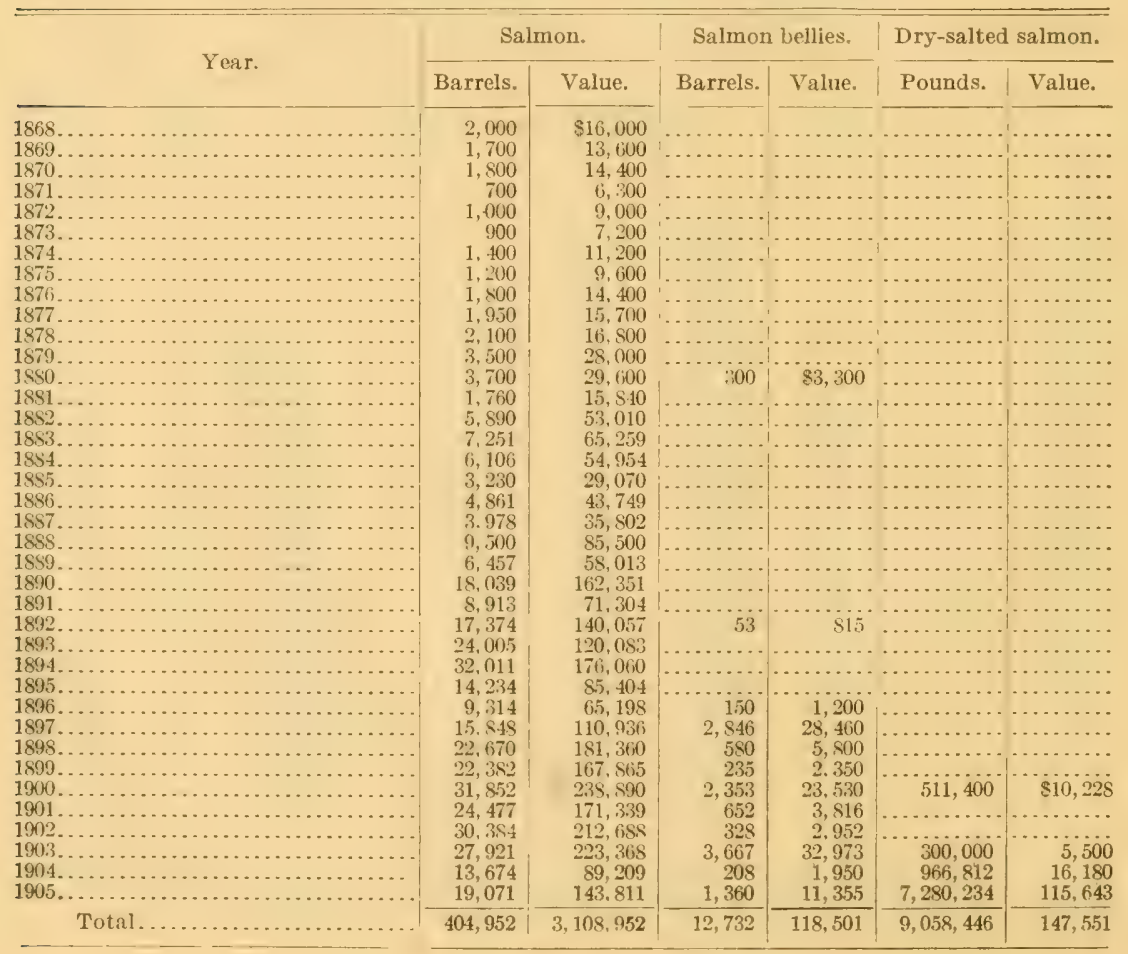


FREEZING SALMON.

The preparing of frozen salmon began in 1902. The San Juan Fishing and Packing Company, soon to be sueceeded by the Pacific Cold Storage Company, pui up a cannery and cold-storage plant at Taku Harbor, Southeast Alaska, in 1901, though it did not operate the coldstorage portion until 1902 . The quantity prepared that year was not reported by the company. It appears that in 1903 the pack was valued at 850,000 and in $1904,57,427$ pounds were frozen. In 1905 the pack was as follows: King salmon, 21,64.3 pounds, valued at $\$ 866$; silver salmon, 22,334 pounds, $\$ \$ 93$; pink salmon, $16,34 \$$ pounds, $\$ 654$, and steelhead trout, 12,306 pounds, $\$ 738$. Nearly all of this frozen fish is shipped to Europe.

The season of 1905 witnessed the inception of a new branch of the salmon fishery. About the middle of January king salmon were observed in the vicinity of Ketchikan, but it was not until January 23 that the first fish were brought to this place for sale. News of the heavy run of fish having spread very rapidly, there were soon a large number of whites and Indians out in canoes catching them. The fish were feeding on the schools of young herring, and as they were cluse to the reefs nets could not be employed, and trolling lines were brought into use. At first herring bait was employed, but it was soon discovered that a nickel trolling spoon would answer the purpose just as well. The vicinity of Point Comano and Point Stewart seemed to be favorite spots for the fish, but they were to be found almost everywhere within a radius of 50 miles from Ketchikan. Several firms in Ketchikan early saw the financial possibilities of the business and soon hat out steamers and launches to collect the fish from the fishing boats and bring them to Ketchikan to be packed in ice and shipped to Puget Sound ports. The fish averaged 25 pounds in weight. One weighed 77 pounds and several 75 pounds each. About 25 per cent of the catch consisted of white-meat fish and 75 per cent of red-meat fish. For the former the fishermen were paid 25 cents each and for the latter 50 cents each. During the run, which lasted until May 1s, 271,644 pounds, valued at $\$ 15,600$, were shipped. A considerable quantity was cured by the Indians for their own use also.

\section{HATCHERIES.}

A few of the more fur-sighted cannerymen early saw the necessity of repairing, by artificial means, the enormous drain upon the supply of salmon caused by the large number of canneries in operation. In 1891 the several canneries in operation at Karluk combined forces and built a hatchery on the lagoon at that place. There were $2,500,000$ eggs taken, but owing to bad water, crude appliances, and want of experience, only about 500,000 fish were hatched. As the cannerymen could not agree in regard to fishing operations in 1892 , the 
hatchery scheme also fell through and the plantwasclosed up. In that year Mr. John C. Callbreath, manager of the Point Ellis cannery, on Kuiu Island, operated a small hatchery on the left bank of Kutlakoo stream. It was a very primitive affair, the work all being conducted without shelter. About 1,000,000 eggs were fertilized and placed in the baskets, but after they commenced hatching an exceptionally high September tide destroyed the plant and it was never rebuilt. During the spring of the same year the Point Ellis cannery burned, and Mr. Callbreath, after sceing to the operation of the hatchery, returned to Wrangell to engage in business. Here his attention was attracted again to hatchery work and he made arrangements with the Indians for the right to Jadjeska stream, which empties into McHenry Inlet on Etolin Island, and in the fall of 1892 built a small hatchery about 200 yards from the mouth of the stream. The stream is about one-half mile in length and is the outlet of a small lake 42 feet above tide water. Finding the location unsuitable, Mr. Callbreath removed the hatchery in 1893 to the northern side of the lake, about three-eighths of a mile from the head of the outlet, where it at present stands. This hatchery is a private enterprise, being unconnected with any cannery or fishery, and is supported wholly by its public spirited and enterprising owner.

In 1896 the Baranof Packing Company, which operated a cannery on Redfish Bay, on the western coast of Baranof Island, built a small hatchery on the lake at the head of Redfish Stream. When 200,000 eggs were in the water very cold weather set in and not only froze the flume solid, but also froze the whole cataract. As the hatchery was thus left without water, the eggs were put into the lake and left to their fate and the hatchery closed down permanently.

In May, 1896, the Alaska Packers' Association broke ground for a hatchery at the eastern end of the Karluk lagoon, near the outlet of Karluk River, and but a short distance from where the hatchery was located in 1891. This was the first large hatchery built in Alaska and at the start had a capacity of several million eggs, which was largely increased from season to season for some years until in 1905 it had a capacity of about $40,000,000$.

In 1897 the North Pacific Trading and Packing Company, at Klawak, Prince of Wales Island, established a hatchery near the head of Klawak stream, close to Klawak Lake. In 1898 the establishment was moved to the mouth of Threemile stream, a lake feeder on the northern side.

The Pacific Steam Whaling Company in 1898 erected a small hatchery on Hetta stream on the west side of Prince of Wales Island, which was operated until the close of the hatching season of 1903-4, when the Pacific Packing and Navigation Company, successor to the original owner, went into the hands of a receiver. This company was the owner of two other small hatcheries also, both built in 1901, one on the stream entering Mink arm of Quadra Bay, on the mainland, and 
one on a stream entering Freshwater Lake Bay, Chatham Strait. These likewise closed when the company failed.

In 1901 the Alaska Packers' Association erected a hatchery on Heckman Lake, the third of a series of lakes on Naha Stream, and about 8 miles from Loring, where the association has a cannery. The association has expended a great deal of money on this hatchery and has made it the largest and most expensive in the world. At present it has a capacity of $110,000,000$ eggs, but it has never been possible to secure enough to fill it.

The Union Packing Company, at Kell Bay, on Kuiu Island, and Mr. F. C. Barnes, at Lake Bay, on Prince of Wales Island, in 1902 built and operated small hatcheries, but with very indifferent success, and both abandoned the attempt after one season's work.

In 1905 the United States Burean of Fisheries took up the work of hatching in Alaska, and began the erection of a hatchery on MeDonald Lake, which empties through a short stream into Yes Bay, on Cleveland Peninsula. As the hatehery proper was not far enough complete to operate when the time for stripping came, in September, the eggs secured were placed in the flume built to bring the water to the hatchery.

Five hatcheries were in operation in 1905-6, and the value of these, together with the Hetta hatchery, which is in condition to operate at any time, is about $\$ 315,000$.

The table below shows the hatcheries which operated successfully from 1892 or at least one season, and gives the number of eggs secured and the number of fry liberated each season. This represents almost wholly redfish, but a few million cohoes having been hatched. The periods represented are fiscal years, because the spawning season, the winter months, covers parts of two calendar years.

Output of the Salmon Hatcheries of 'Alaska, 1893 to 1906.

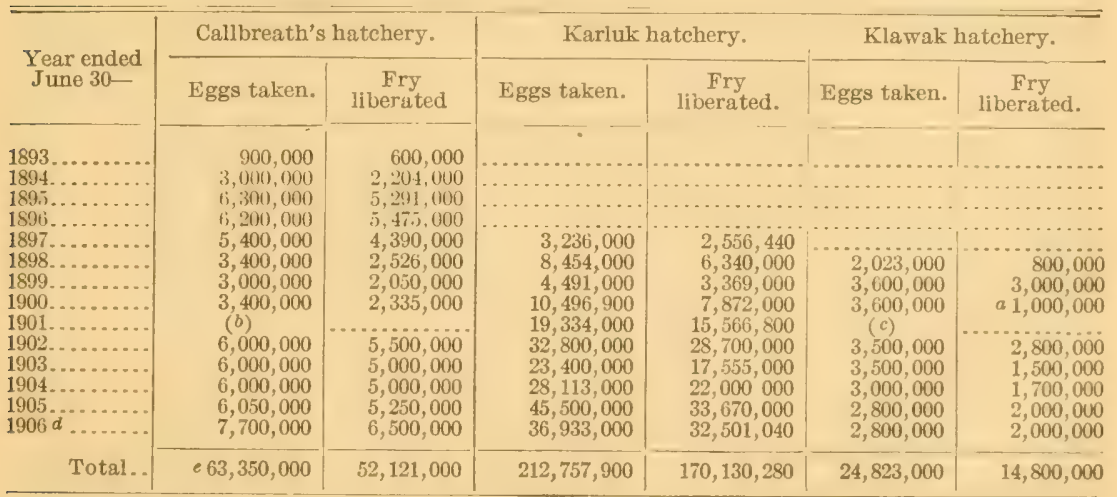

a A hard freeze killed most of the eggs.

o None stripped.

c Eggs all frozen.

c Ag the take of eggs for $1905-6$ had not been hatched out when this report was prepared, tho number of fry had to be estirnated.

$e$ The number of eggs taken in each season at this hatchery has been estimated. 
Output of the Salmon Hatcheries of Alaska, 1893 to 1906-Continued.

\begin{tabular}{|c|c|c|c|c|c|c|c|c|c|c|c|c|}
\hline \multirow{2}{*}{$\begin{array}{c}\text { Year ended } \\
\text { June } 30-\end{array}$} & \multicolumn{3}{|c|}{ Hetta hatchery. } & \multicolumn{3}{|c|}{$\begin{array}{c}\text { Quadra Bay } \\
\text { hatchery. }\end{array}$} & \multicolumn{3}{|c|}{$\begin{array}{c}\text { Freshwater Bay } \\
\text { hatchery. }\end{array}$} & \multicolumn{3}{|c|}{$\begin{array}{l}\text { Fortmann } \\
\text { hatchery. }\end{array}$} \\
\hline & $\begin{array}{l}\text { Eggs } \\
\text { taken. }\end{array}$ & \multicolumn{2}{|c|}{$\begin{array}{c}\text { Fry } \\
\text { liberated. }\end{array}$} & \multicolumn{2}{|c|}{$\begin{array}{l}\text { Eggs } \\
\text { taken. }\end{array}$} & $\begin{array}{c}\text { Fry } \\
\text { liberated. }\end{array}$ & $\begin{array}{l}\text { Eggs } \\
\text { taken. }\end{array}$ & \multicolumn{2}{|c|}{$\begin{array}{l}\text { Fry } \\
\text { Iiberated. }\end{array}$} & \multicolumn{2}{|c|}{$\begin{array}{l}\text { Fggs } \\
\text { taken. }\end{array}$} & $\begin{array}{l}\text { Fry } \\
\text { liberated. }\end{array}$ \\
\hline \multirow{13}{*}{ 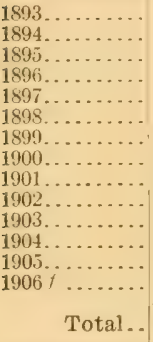 } & & \multicolumn{2}{|c|}{$\ldots \ldots \ldots$} & \multirow{2}{*}{\multicolumn{2}{|c|}{$\begin{array}{l}- \\
\ldots \ldots \ldots \ldots \\
\ldots \ldots \ldots \ldots\end{array}$}} & \multirow{2}{*}{$\mid \begin{array}{l} \\
\ldots \ldots \ldots \ldots \\
\ldots \ldots \ldots \ldots\end{array}$} & \multirow{2}{*}{$\begin{array}{l} \\
\ldots \ldots \ldots \\
\ldots \ldots \ldots \ldots\end{array}$} & \multicolumn{2}{|c|}{$\ldots \ldots \ldots$} & \multicolumn{2}{|c|}{...... } & \\
\hline & $\cdots$ & \multirow{2}{*}{\multicolumn{2}{|c|}{$\begin{array}{l}\ldots \ldots \ldots \ldots \\
\ldots \ldots \ldots \ldots \\
\ldots \ldots \ldots \ldots\end{array}$}} & & & & & \multicolumn{2}{|c|}{$\ldots \ldots \ldots \ldots$} & \multicolumn{2}{|c|}{$\ldots \ldots \ldots \ldots$} & \\
\hline & & & & \multicolumn{2}{|c|}{$\ldots \ldots \ldots$} & & & \multicolumn{4}{|c|}{ 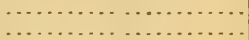 } & \\
\hline & & \multirow{2}{*}{\multicolumn{2}{|c|}{$\ldots$}} & \multirow{2}{*}{\multicolumn{2}{|c|}{ $\ldots \ldots$}} & & & & & & & \\
\hline & & & & & & & & & & & & \\
\hline & $\begin{array}{l}2,800,000 \\
2,000,000\end{array}$ & & 00,000 & & & & & & & & & $\cdots$ \\
\hline & $1,800,000$ & & 00,000 & & & & & & & & & \\
\hline & $2,500,000$ & & 00,000 & 4,500 &, 000 & 3,500 , & $1,500,000$ & & $, 000,000$ & 11,460 & & 10,30 \\
\hline & $4,800,000$ & & 00,000 & 5,500 &, 000 & $4,000,000$ & (b) & & (b) & 40,050 & & 000 \\
\hline & $5,127,500$ & & 750,000 & 600 & 000 & c 400,000 & (d) & & (d) & 22,203 & & 13 \\
\hline & & & & & & (e) & $(c)$ & & (e) & 65,010 & & 63 \\
\hline & (e) & & (e) & & & (e) & (e) & & (e) & 71,139 & & 65 , \\
\hline & $19,027,500$ & & 050,000 & 10,600 & & $7,900,000$ & $1,500,000$ & & $, 000,000$ & 209,862 & & $181,579,710$ \\
\hline & Kell B & & her & & & MeDonald & hatchery. & & & & & \\
\hline June $30-$ & Eggs take & & $\begin{array}{l}\text { Fry } \\
\text { libera }\end{array}$ & ted. & Eg\& & gs taken. & Fry plant & ed. & Eggs t & aken. & & $\begin{array}{l}\text { Fry } \\
\text { iberated. }\end{array}$ \\
\hline 1893. & & & & & & & & & & 000 & & 000 \\
\hline & & & & & & & & & & & & \\
\hline & & & & & & & & & & 300 & & \\
\hline .... & $\cdots$ & & & $\ldots$ & $\ldots$ & $\cdots$ & & & & 00,000 & & \\
\hline 1897. & - . & & $\ldots$ & $\ldots$ & & ....... & $\ldots \ldots$ & & & 36,000 & & \\
\hline$\ldots$. & $\cdots$ & & $\ldots$ & $\ldots$ & $\ldots$ & ... & $\ldots$. & & & & & \\
\hline & & & & & & & & & & $1, \mathrm{C}$ & & 9,000 \\
\hline $1900 \ldots$ & & & & & & & & & - 19 , & 6,900 & & 7,000 \\
\hline $1901 \ldots$ & . & & & & & & & & & 4,000 & & 6,800 \\
\hline 1902 & & & & & & & & & & 0,000 & & 0,000 \\
\hline 190 & $2,500,0$ & & 2,00 & 0,000 & & & & & & 50,000 & & 600,000 \\
\hline 190 & (e) & & (e) & & & ...... & & & & 3,500 & & $46,630,000$ \\
\hline & (e) & & (e) & & & - & & & 119 & -000 & & 104, \\
\hline $1906 f$... & (e) & & & & & $7,000,000$ & $5,000,0$ & & 125 & 72,000 & & $111,314,750$ \\
\hline Total.. & 2,500, & & 2,00 & 0,000 & & $7,000,000$ & $5,000,0$ & & 551,4 & 20,400 & & $448,580,990$ \\
\hline
\end{tabular}

a Many eggs frozen

$b$ No run of fish.

$c$ Hatchery was not used, the eggs being hatched out in the lake.

d No report.

e Not operated.

$f$ As the take of eggs for 1905-6 had not been hatched when this report was prepared, the number of fry had to be estimated.

\section{FERTILIZER PLANTS.}

As noted elsewhere, the Alaska Oil and Guano Company has operated a herring fertilizer plant at Killisnoo for some years. During 1905 the Alaska Fish and Development Company, at Pleasant Bay, built a small fertilizer plant in an old hulk, which can be moved from place to place as desired. The company expects, when the plant is working, to utilize the salmon and herring offal from its saltery.

The Pacific Coast and Norway Packing Company also put in a small fertilizer plant in connection with its salmon cannery at Tonka in 1905. The plant cost about $\$ 3,500$ and will have a capacity of 12 tons daily. The intention is to use the waste product of the cannery, and as the noxious gases which make a fertilizer plant so offensive are piped off into the furnace and there consumed it has been possible to build the plant immediately alongside the cannery building. The manager of the cannery estimates that when reduced a ton of salmon offal will make from 400 to 500 pounds of fertilizer and 150 pounds (about 20 gallons) of oil. 
In 1904 the North Pacific Fish and Oil Company established a fertilizer plant at Grace IIarbor, on Dall Island. It was the intention of the company to utilize the offal from a nearby salmon saltery and also such little used species as mud sharks, dogfish, etc. Unfortunately the plant proved unworkable and has not yet been remodeled to suit Alaskan conditions.

As the offal from the salmon canneries alone amounts to over $35,000,000$ pounds in a season, all of which is at present thrown orerboard and allowed to pollute the waters, it is easily to be seen that if small fertilizer plants could be installed at each cannery to treat this offal, as is done at the sardine canneries in Maine, this enormous annual wastage would be obviated and the waters adjacent to the canneries rendered more agreeable, not only to the denizens of the water but also to the chance visitor.

Oil.-For many years the Indians have engaged in catching the dogfish (Squalus sucklii Girard) and extracting from it an oil which they sell to the traders. Loring has always been a favorite resort for these fishermen, as the dogfish are especially abundant in that vicinity. It is estimated that as nuch as 10,000 gallons of this oil were obtained in 1892. The only firm of white men engager in this business at present is the Ketchikan Ka-ko Oil Company, which has a small plant at Loring. The livers alone are utilized, the rest of the fisn being thrown away. The oil, because of its heavy body and freedom from grit, is a most desirable lubricant and finds a ready sale in logging camps as "skid grease." In 1904 the company refined part of its product and is now endeavoring to introduce it as a medicinal oil, for which they claim it is well suited.

\section{AQUATIC FURS.}

Of the fow industries followed in Alaska that of hunting the furbearing animals is one of the most important. Owing to the immense extent of territory still unoccupied except by a few sniall tribes of Indians or Eskimos, it is probable that the industry, so far as it relates to aquatic animals in the interior waters, will thrive for some years to come. Those fur-bearing animals, such as the seal and sea otter, found along the shores of the mainland and adjacent islands and the open sea, where they can easily be hunted, are rapidly becoming extinct. This fact has already had a rery important bearing on the welfare of the coast tribes, as they have been dependent at many places upon their catch of these animals for the means wherewith to secure the very necessaries of life.

The fur traders have their stations located at convenient points, and from these in the spring and summer send out ressels to risit branch stations or certain rendezvous, where they secure from the natives their catch of the past year and pay for the same in goods. In the interior the traders usually fit out trusty natives with small 
stocks of groods to travel amoing those more distant tribes which can not reach the stations. The prices paid are regulated by the standard price of red fox or marten, called 1 skin, which in 1890 was about \$1.25. In 1890 a prime beaver was put in as 2 skins; black bear, 4 skins; lynx, 1 skin; land otter, 2 or 3 skins. Five yards of drilling or 1 pound of tea or 1 pound of powder, or half a pound of powder with 1 box of caps and 1 pound of shot, are given for 1 skin; 50 pounds of flour for 4 skins; 5 pounds of sugar for 1 skin. In the mining districts the prices are much higher, to conform to those paid by the miners.

Beaver.-This is the most valuable of the fur-bearing aquatic animals of the interior waters of Alaska, and since the district was acquired by the United States has been hunted with such vigor that its numbers are very much diminished and diminishing. The range of this animal covers all of the mainland of Alaska, excepting only the belt of barren-coast country bordering the Arctic Ocean from Point Hope north and east to the Canadian line. The numerous lakes and ponds and the clear streams of the interior, especially those bordered by alders and willows, are the beaver's favorite resorts. It generally avoids the large rivers, owing to the great change in level likely to occur at different seasons. The natives catch beavers in steel traps set at a frequented spot or shoot them from a concealed place near their house or dam. The natives of eastern Siberia prize the fur of the beaver very highly for trimming their fur clothing, and during the summer months many of the skins are taken across Bering Straits by the Eskimos and traded to the Siberian natives for the skins of the tame reindeer. Castoreum, an oily odorous compound secreted by the preputial glands of the animal, also the dried preputial follicles and their contents, are sometimes prepared and find a sale in China, where they occupy a place in the pharmacopœia. Iil 1905 but 5 pounds, valued at about $\$ 16$, were prepared. From 1745 to 1867 , the period covered by the Russian occupation of Alaska, 413,356 beaver skins were secured by her traders.

Muskrat.-Wherever bogs and ponds or running water occur on the mainland, except along the extreme northern coast line, this animal will be found; it is also found upon Nunevak and St. Michaels islands. It is trapped in small steel traps or in wicker fish traps. The greater part of the skins are bought by the traders for the purpose of bartering them ofl in other localities for more valuable furs, hence but few of them reach the outside world. They are used by the natives for making fur clothing and blankets or robes.

Land otter. - This species is one of the most widely distributed in the district, being found on the whole coast of Alaska from the southern boundary to the northern shore of Norton Sound. It also occurs on all the islands insitle of these limits as far as Unimak in the west and Nunivak in the north. IVithin the Arctic Circle it is confined to the 
upper courses of the rivers emptying into the Arctic Ocean. It is quite generally distributed over the interior of the Territory and is also found on the Kadiak Archipelago. The land otters found upon Sitkalidak, one of the Kadiak group, are famous for their very dark fur. A steel trap is generally used in capturing the animal. According to Russian records 244,538 of these skins were bought by the traders from 1745 to 1867 , the date of American annexation. Since then the supply has remained fairly constant.

Sea otter.-When Bering and his party first explored the Aleutian Islands in 1760-1765 they found the sea otters exceedingly numerous all along the Aleutian chain. They are now almost unknown around a greater part of it, their principal resort at present being among the reefs and outlying islets surrounding Sannak Island, near the eastern end and on the Pacific side of the chain. The Aleutian hunters are brought to this point in vessels belonging to the trading companies and to private individuals, and landed with their bidarkas or skin canoes and hunting equipment. Here they remain for months, scouring the sea in all directions or lying upon rocky points and islets awaiting the approach of an otter within long rifle shot. The fur of this animal is the most valuable in the world. Even as far back as 1980 from $\$ 80$ to $\$ 100$ in cash were paid by the traders to the Aleuts for particularly fine skins. At the London sales in 1888 the average price received for these skins was $£ 2110$ s.; in 1889 , £33; and in 1891 , $£ 57$. A single skin, however, has sold for as high as $\$ 1,400$, and in 1905 a trader at Nome valued one skin which he has secured at $\$ 2,000$. During the Russian occupation (from 1745 to 1867 ) 260,790 sea otter skins are reported as having been shipped from Alaska.

The following table shows the number and value of the aquatic furs, other than seal, obtained in Alaska and shipped from the district from 1868 to 1905 , both inclusive:

Aquatio Furs Obtained in Araska, 1868 to $1905{ }^{a}$

\begin{tabular}{|c|c|c|c|c|c|c|c|c|c|c|}
\hline \multirow{2}{*}{ Year. } & \multicolumn{2}{|c|}{ Beaver. } & \multicolumn{2}{|c|}{ Muskrat. } & \multicolumn{2}{|c|}{ Otter, land. } & \multicolumn{2}{|c|}{ Otter, sea. } & \multicolumn{2}{|c|}{ Totai. } \\
\hline & $\begin{array}{l}\text { Num- } \\
\text { ber. }\end{array}$ & Value. & $\begin{array}{c}\text { Num- } \\
\text { ber. }\end{array}$ & Value. & $\begin{array}{c}\text { Num- } \\
\text { bet. }\end{array}$ & Value. & $\begin{array}{l}\text { Num- } \\
\text { ber. }\end{array}$ & Value. & $\begin{array}{c}\text { Num- } \\
\text { ber. }\end{array}$ & Value. \\
\hline $\begin{array}{l}1869-1870 \ldots . . \\
1871-1880 \ldots . . \\
1881-1890 \ldots . \\
1891-1900 \ldots . \\
1901-1904 \ldots . \\
1905 \ldots . \ldots\end{array}$ & $\begin{array}{r}17,041 \\
41,217 \\
60,940 \\
21,810 \\
7,740 \\
1,935 \\
\end{array}$ & $\begin{array}{r}\$ 85,205 \\
200,085 \\
304,700 \\
109,050 \\
38,700 \\
8,271 \\
\end{array}$ & $\begin{array}{l}17,908 \\
50,322 \\
90,000 \\
30,000 \\
50,396 \\
12,593 \\
\end{array}$ & $\begin{array}{r}\$ 895 \\
2,516 \\
4,500 \\
1,500 \\
2,520 \\
1,192 \\
\end{array}$ & $\begin{array}{r}6,367 \\
27,730 \\
27,730 \\
21,000 \\
8,556 \\
1,859 \\
\end{array}$ & $\begin{array}{r}\$ 31,835 \\
138,650 \\
138,650 \\
105,000 \\
68,448 \\
14,458 \\
\end{array}$ & $\begin{array}{r}12,208 \\
40,283 \\
47,812 \\
6,467 \\
260 \\
61\end{array}$ & $\begin{array}{r}\$ 1,220,800 \\
4,028,300 \\
4,784,200 \\
616,700 \\
39,000 \\
13,867\end{array}$ & $\begin{array}{r}53,524 \\
159,552 \\
226,512 \\
79,277 \\
66,952 \\
16,484\end{array}$ & $\begin{array}{r}\$ 1,338,735 \\
4,375,551 \\
5,232,050 \\
862,250 \\
148,658 \\
37,785\end{array}$ \\
\hline Total.. & 150,693 & 752,011 & 251.225 & 13,123 & 93,272 & $49 \pi, 011$ & $10 \pi, 1: 21$ & 10.732 .867 & 602,301 & $11,095,042$ \\
\hline
\end{tabular}

a The values given, except in 1905 , are the prices realized in London.

Fur seal.-It would be superfluous to go into any detail in regard to the general subject of the fur seal, as the existing literature deroted to this animal would constitute a large library in itself. The only breeding grounds are on the islands of St. Paul and St. George in Bering Sea. From about 1745 until the district of Alaska was annexed 
to the United States in 1867 the Russians took from these islands $3,354,478$ skins. In 1870 the Alaska Commercial Company secured from the Government the exclusive right to kill fur seals on the islands, and retained this right until 1890 , when it was succeeded by the North American Commercial Company, which is still in possession. The decrease in the number of seals sirce 1867 has been enormous. It is estimated that in 1867 the herd numbered about 5,000,000, while in 1905 it was only about 200,000 . A considerable part of this decrease is attributed to the killing of female seals by the pelagic sealing vessels. On their way to the breeding grounds the weals follow the coast line from Santa Barbara Channel northward and throughout this journey they are eagerly sought by the pelagic sealers. A little measure of relief to the harassed herd was extended by the decision of the Bering Sea Arbitration Tribual in 1893, but the slaughter was soon resumed. The table below shows the catch of fur seals from 1867 to date both on the islands and from pelagic and other sources, presumably within Alaskan waters. The values given are those received in London at the great auction sales held there several times each year.

Fur-Seal Skins Obtained from the Seal Islands and from Pelagid and Other Sources, All in Waters of Alaska, 1868 to 1905.

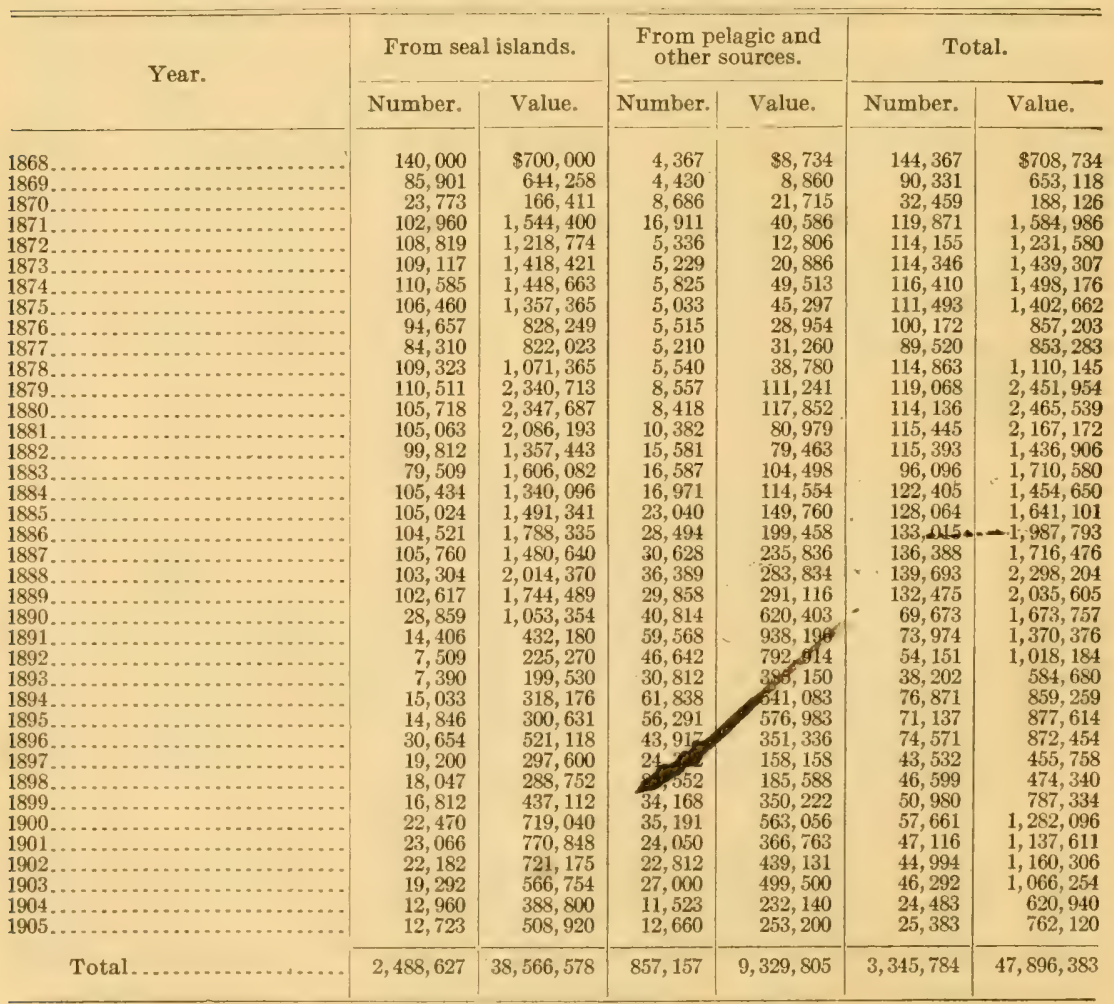


At one time it was thought that the problem of furnishing a permanent supply of food for the natives on the Pribilof and Aleutian groups could be solved by salting the careasses of the fur seals and shipping these to the various settlements. In 1880, 1,000,000 pounds, valued at $\$ 10,000$, were so prepared, but owing to the fact that the meat did not keep very well, and to other causes, the project was soon abandoned. The natives living on the Pribilof group, however, still depend quite largely upon the seal carcasses for food.

\section{MISCELLANEOUS AQUATIC ANIMALS.}

Grampus.-This mammal, commonly known as the beluga in Alaska, is quite abundant in the summer along the Alaskan coast north of the Aleutian chain, being particularly numerous about the mouths of rivers and frequently ascending the larger streams far above tide water. It is migratory, and its movements are regulated by the ice. The numerous tidal creeks along the low flat coast from St. Michaels to the Kuskoquim River, in which tomeods are abundant, are the chief resort of the beluga, which comes in to feed on the fish. The Eskimos catch them with strong, large-meshed nets, heavily weighted, set off outlying points. In rough weather, when the animals can not see the nets, many are taken, but in clear weather the catch is small. Some are speared, some shot, but unless the shot goes through the spinal column these generally escape. The flesh of a young beluga is tender and not unpalatable, but is rather coarse and dry. The fat, or blubber, is clear and white and is highly valued by the natives, who extract the oil from it and use it in barter with the interior tribes. The intestines are made into waterproof garments or floats, and the sinews are very much prized. The small ivory teeth are carved into toys or ornamental pendants, while the skin is made into strong lines or very durable boot soles. The epidermis, which is nearly half an inch thick, when well cooked is considered choice eating, having a flavor somewhat resembling chestnuts.

Hair seals. - While these animals form a very insignificant part of the commerce in which the white traders participate, owing to the fact that their fur is worthless, they are of immense importance to the natives, for from the flesh and oil is secured a considerable part of their winter food, while the skins are highly prized for covering the kyacks and umiaks and for boot soles, trousers, mittens, clothing bags, and caps, and when cut into strips make a very strong and durable cord. The skin in its raw state is thick and unwieldy, but when nicely tanned becomes soft and pliable. The coast natives also barter the flesh, oil, and skins with the interior tribes for reindeer hides and furs, thus creating a very important branch of trade, of which it is impossible to form an idea, owing to the inaccessibility of 
most of the tribes. The very fragmentary record kept of the skins sold to white traders shows that in $1889,3,500$ skins, valued at $\$ 7,000$, in $1890,3,444$, valued at $\$ 6,888$, and in $1905,9,098$ skins, valued at $\$ 5,554$, were so disposed of. These meager figures are probably too low.

The species taken are the bearded seal (Erignathus barbatus); the ribbon seal (Phoca fasciata), a rare species; the ringed seal (Phoca fotida), the most common; the harp seal (Phoca grcenlandica), quite rare; and the harbor seal (Phoca vitulina), which is quite common and the most widely distributed.

When the ice leaves the coast the natives hunt the seals in kyacks, using a light spear or a rifle. At this season many of the ringed seal are found upon the ice packs well offshore and are taken by the Eskimo in a curious manner. The latter wear a shirt made of white sheeting, and, paddling cautiously up to a piece of ice on which the seals are gathered, are enabled by means of the disguise to land and get among the seals without alarming them, and sometimes kill quite a number with a club before the herd takes flight. When the cold storms of September set in the seals return along shore again and seek refuge in the inner bays and sheltered coves. At this season the natives set many rawhide nets with large meshes off the rocky points, and large numbers are taken thus. Later, when the sea is frozen over, nets are set about the holes which the seals make in order to be able to come to the surface to breathe. Many of the seals also are killed at these holes by the hunters armed with spears.

Steller's sea lion.--This animal, which at one time was extremely abundant on the Pribilof Islands and along the Aleutian chain, is now almost extinct. A few still haul up on the former islands, but they are becoming less and less each year, a fact which means a serious loss to the natives, as they made more use of this animal than of any other they hunted. Its skin, flesh, intestines, bones, sinews, and oil all came into play as food or in the primitive manufactures. The skins were considered an indispensable covering for the umiak, or large canoe, used in hunting, and after the animal became practically extinct on the Aleutian chain the traders imported such skins from the coast of Lower California and Mexico for the use of their hunters. The sea lion never became other than a subject of intertribal barter.

Walrus.-This enormous mammal, which is not found south of the Bering Sea shore of the Aleutian chain, was at one time very numerous north of there, and the hunting of it and the seal formed the principal occupation of the Eskimos during the summer. It goes north as the ice breaks up in spring and returns again in the fall, stopping but a short time at any spot, and keeping close to the ice pack all this time. When in the water it is hunted by the Eskimos in kyacks, with 
ivory-pointed spears and seal-skin line and floats. When the animal is exhausted by its efforts to escape the hunter's draw near and give the death stroke with a lance.

Aceording to The Friend, published at Honolulu, IIawaii, March 1, 1872, the whalers began to turn their attention to walrus-catching about the year 1868. During the first part of every season there is but little opportunity to capture whales, they being within the limits of the icy barrier. As a result, much of the whaler's time during July and August was devoted to capturing walruses. Men would be landed on the shore in June and left to watch for the animals to haul up) on the beach at certain points. The walrus must either come ashore or get on the ice, and when a herd is well ashore one or two old bulls are generally left on watch. The best shot among the hunters now creeps up, and by a successful rifle shot or two kills the guard. Owing to their very defective hearing, the noise made by the rifle does not awake them. The gun is then put aside and each hunter, armed with a sharp ax, approaches the sleeping animals and cuts the spines of as many of them as possible before the others become alarmed and stampede for the water and escape.

The white hunters rarely make use of anything but the two long, curved tusks with which the animal is equipped and which arerage about 5 pounds to the pair. If time permits, however, the flesh is boiled and the oil saved. To many of the Eskimos, especially on the Aretic shore, the walrus is almost a necessity of life, and the derastation wrought among the herds by the whalers has been, and is yet, the cause of fearful suffering and death to many of the natives. The flesh is food for men and dogs; the oil also is used for food and for lighting and heating the houses; the skin, when tanned and oiled, makes a durable cover for the large skin boats; the intestines make waterproof clothing, window-covers, and floats; the tusks are used for lance or spear points or are carved into a great variety of useful and ornamental objects, and the bones are used to make heads for spears and for other purposes. At the present time the Kuskoquim distriet is the only one in which the walrus is fairly common.

In addition to hunting the walrus themselves, the whalers also purchase from the Eskimos the tusks, or irory, that they have secured. The table on page 36 shows the quantity and value of walrus oil and ivory secured sinee 1868. Part of this was undoubtedly secured from the natives of siberia, but that is more than offset by the large quantity which has been brought down by the whalers and not reported. 
Walrus Ivory and Orl Secured in Alaska, 1868 to 1905.

\begin{tabular}{|c|c|c|c|c|c|c|c|c|c|}
\hline \multirow{2}{*}{ Year. } & \multicolumn{2}{|c|}{ Ivory. } & \multicolumn{2}{|c|}{ Oil. } & \multirow{2}{*}{ Year. } & \multicolumn{2}{|c|}{ Ivory. } & \multicolumn{2}{|c|}{ Oil. } \\
\hline & Pounds. & Valne. & Gillons. & Value. & & Pounds. & Value. & Gallons. & Value. \\
\hline $\begin{array}{l}1868 \ldots \\
1869 \ldots \\
1870 \ldots \\
1871 \ldots \\
1872 \ldots \\
1873 \ldots \\
1874 \ldots \\
1875 \ldots\end{array}$ & $\begin{array}{l}40,000 \\
70,000 \\
63,800 \\
37,600 \\
32,000 \\
44,000 \\
33,000 \\
25,400\end{array}$ & $\begin{array}{r}\$ 2,000 \\
3,500 \\
3,190 \\
3,760 \\
3,200 \\
4,400 \\
3,300 \\
3,810\end{array}$ & $\begin{array}{l}173,000 \\
303,000 \\
315,000 \\
189,000 \\
160,000 \\
220,500 \\
165,000 \\
126,000\end{array}$ & $\begin{array}{r}\$ 86.500 \\
166,650 \\
163,800 \\
101,200 \\
128,000 \\
50,000 \\
74,250 \\
81,900\end{array}$ & $\begin{array}{l}1888 \ldots . . . \\
1889 \ldots . . \\
1890 \ldots . \\
1891 \ldots . \\
1892 \ldots . \\
1893 . \ldots \\
1894 \ldots \\
1895 a . . .\end{array}$ & $\begin{array}{r}5,158 \\
6,228 \\
5,799 \\
5,200 \\
4,800 \\
7,900 \\
12,313\end{array}$ & $\begin{array}{r}\$ 5,158 \\
4,982 \\
4,639 \\
3,900 \\
3,360 \\
6,320 \\
9,850\end{array}$ & $\begin{array}{l}22,351 \\
26,988 \\
25,129 \\
20,000 \\
18,196 \\
21,400 \\
15,100\end{array}$ & $\begin{array}{r}810,505 \\
13,594 \\
9,549 \\
9,800 \\
8,006 \\
9,630 \\
5,534\end{array}$ \\
\hline 1876. & 31,500 & 4,725 & 157,500 & 157,500 & $1896 \ldots$ & 10,000 & 8,000 & 12,444 & 4,604 \\
\hline & 74,000 & 14,800 & 221,000 & 44,200 & 1897. & 41,714 & 31,286 & 8,400 & 3,360 \\
\hline $\begin{array}{l}1878 . \\
1879 .\end{array}$ & $\begin{array}{l}30,000 \\
38,318\end{array}$ & $\begin{array}{r}6,000 \\
\end{array}$ & 125,000 & 56,250 & $\begin{array}{l}1898 \\
1899\end{array}$ & $\begin{array}{l}25,700 \\
22,300\end{array}$ & 17,990 & 5,111 & 1,845 \\
\hline $\begin{array}{l}1879^{-} \\
1880 .\end{array}$ & $\begin{array}{l}58,318 \\
24,650\end{array}$ & $\begin{array}{l}19,159 \\
24,650\end{array}$ & $\begin{array}{l}190,000 \\
127,000\end{array}$ & $\begin{array}{l}76,000 \\
57,150\end{array}$ & 1900. & & $\begin{array}{r}10,725 \\
5,969\end{array}$ & 2,200 & $\begin{array}{r}2,350 \\
880\end{array}$ \\
\hline 1881 . & 19,475 & 19,475 & 84,392 & 60,762 & 1901. & 7,000 & 7,000 & 1,200 & 480 \\
\hline 1882. & 22,085 & 22,085 & 95,702 & 38,281 & 1902. & 12,491 & 9,993 & 1,800 & \\
\hline & $\begin{array}{r}27,725 \\
7026\end{array}$ & 20,794 & 120,142 & 108,128 & $1903 .$. & 14,100 & 11,985 & 700 & 280 \\
\hline & $\begin{array}{l}7,026 \\
6,564\end{array}$ & $\begin{array}{l}7,026 \\
6,564\end{array}$ & $\begin{array}{l}30,446 \\
28,444\end{array}$ & $\begin{array}{l}15,527 \\
12,800\end{array}$ & $\begin{array}{l}1904 \ldots \\
1905 \ldots\end{array}$ & $\begin{array}{r}8,500 \\
11,335\end{array}$ & $\begin{array}{l}6,800 \\
8,213\end{array}$ & 1,000 & 400 \\
\hline $\begin{array}{l}1886 \ldots \\
1887 \ldots\end{array}$ & $\begin{array}{l}3.550 \\
6,730\end{array}$ & $\begin{array}{l}3,5,50 \\
5,384\end{array}$ & $\begin{array}{l}15,383 \\
29,163\end{array}$ & $\begin{array}{r}5,692 \\
16,040\end{array}$ & Total. & 843,930 & 343,542 & $3,064,001$ & $1,582,219$ \\
\hline & & & & & & & & & \\
\hline
\end{tabular}

a Data missing.

Whales.--Thaling at the present time is participated in to a very limited extent by the natives of Alaska, the Eskimos living along the Arctic coast being the only ones engaged. At one time, however, the natires of the Aleutian chain and the shores of Bering Sea followed whaling whenever possible during the summer months. As from the beginning, almost all of the whaling is done by the fleet which rendezvous at San Francisco. About 1867 from 10 to 12 of these whaler's risited what are known as the Kadiak grounds, but this ground was soon exhausted and the whole fleet now works exclusively in the Arctic. Large numbers of humpback whales (Megaptera versabitis) are to be seen during the summer months in southeast Alaska, but no effort is made to capture them. The bowhead (Balæna mysticetus) is the common Arctic whale, and the one generally secured by the whalers, although a few right whales (Balæna sieboldii) are taken in certain seasons. The principal object of whale fishing at the present time is the whalebone, which brings as much as $\$ 5$ per pound in the markets. As the whaling fleet generally pursues its prey in the open sea and has its headquarters outside of Alaska, its work does not come within the scope of this report except as it deals with the natives.

The belt of open water bordering the American coast from Icy Cape to the mouth of the Colville River is a farorite resort for whales during the latter part of summer and until winter sets in. From Icy Cape to Point Barrow the coast is low and sandy and backed by shallow lasoons, its southern portion being known to whalemen as the "graveyard," owing to the great number of vessels that have been wrecked there. It is along this stretch of coast that the natives do their whaling. In April the ice pack begins to loosen, and soon there 
are cracks, or "leads," as they are called, open 6 or 7 miles from the shore, extending often for miles parallel to the land, but continually changing, frequently disappearing altogether as the wind reers. It is in these "leads" of open water that the whales work their way to their unknown breeding grounds in the northeast, passing by Point Barrow chiefly during the months of May and June.

Each village fits out as many boats as it can supply with crews. The crews, 8 or 10 men to the boat, or oceasionally women when men are scarce, are selected during the winter. The owner, who is always the captain and steersman, sometimes hires them outright, paring them with goods, and sometimes he allows them to share in the profit:; he always feeds them while the boat is in commission. The harpooner is posted in the bow, while another man, armed with a bomb gun, is located amidships. As soon as a whale is seen the boat is launched and the pursuit begun. Instead of harpooning the whale and keeping the end of the line fast in the boat, which the whale is compelled to drag about until the crew can manage to haul up and lance him to death, as is the practice of the white whalers, the Eskimos have but a short line attached to each harpoon, to the end of which are fastened two floats made of whole sealskins inflated, which are thrown overboard as soon as the harpoon is fixed in the whale. Each boat carries four or five harpoons, and as many boats as possible crowd around and endeavor to drive a harpoon into the whale each time he comes to the surface, until he can dive no longer and lies upon the water ready for the death stroke, which is griven with a lance. Occasionally an opportunity oecurs to use the bomb gun as soon ats the whale is struck, and the contest is then ended at once. Is soron as killed, the whale is towed to the edge of the solid floe and the work of cutting him up begins. The skin, blubber, and flesh, according to a custom universal among the Eskimos, belong to the whole community, no matter who killed it, but at Point Barrow the whalebone must be equally divided among all the boats that were in sight when the whale was killed. Everything is soon carried home to the rillage. The blubber is not tried out, but is packed away in bags made of whole sealskins, and with the meat is stowed away in little underground chambers, of which there are many in the villages.

There is very little data showing the extent of the whaling as followed by the Eskimos. In 1891 they took from 10 to 15 whales, while in 1892-a very poor season, owing to the larege quantities of ice on the eastern shore at the time the whales were passing north-about 15,000 pounds of whalebone were secured. In 1905, s,057 pounds of bone, valued at $\$ 51,197$, were taken. All of the bone sireured by the natives is sold to the whaling ressels, and it is very probable that large quantities so obtained in barter are reported at the home port as part of the catch of the vessel. In $18 S 0$ it is estimated that nativen 
put up 5,000 gallons of whale oil, valued at $\$ 500$. During the period from 1883 to 1889 , both inclusive, the Alaska Commercial. Company shipped 33 packages of whalebone from Alaska. The weight and value of the packages are not given. In 1882, 166 barrels and in 1889,13 barrels of whale oil were shipped from Alaska by the same company.

\section{GENERAL STATISTICS FOR I905.}

The fisheries of Southeast Alaska in 1905 were canvassed by the writer in person; the figures for the salmon fisheries of Central and Western Alaski are compiled from the reports sent in by the canneries and salteries to the agent at the salmon fisheries of Alaska; data for the cod and other fisheries of the same sections were secured either by personal interviews or by correspondence with the owners of fishing vessels and stations, nearly all of whom are located either in California or Washington; the yield of fur seals from the Pribilof group was obtained from the report of the agent at the fur seal islands, and of the balance of the fur seals and the other aquatic furs and skins, also the whalebone, walrus ivory, etc., from the customhouse records at Juneau, Alaska. The custom-house records show the fiscal year (1904-5); all other data in the following tables represent the calendar year 1905 .

In order that the data might be shown with greater clearness, the district has been divided into four geogriphicul sections. Southeast. Alaska embraces all that narrow strip of mainland and the numerous islands adjacent, from Portland Canal northwestward to, but not including, Yakutat Bıy; Central Alaskit embraces everything on the Pacific, or south, side from Yakutat Bay westward, including the Aleutian chain; Western Alaska the shores of Bering Se: and islands in this sea; and Aretic Alaska, from Bering Strait to the Canadian border. As these divisions are already quite generally recognized throughout the district, their use here will not be confusing.

The number of persons employed was 11,467 , of which 4,028 were engaged directly in fishing and 6,856 in the camneries, salteries, and other shore work, while 583 were employed on the transporting vessels. In the sulmon fishery the employees of the cannery or saltery are usually taken to the latter place aboard a sailing vessel, which remains until the season's work is ended, when she returns to the home port with the employees and the season's pack. While lying idle during the fishing season most of the crew, not being needed aboard the ship, are employed as fishermen, and have been counted as such, thus materislly reducing the number of transporters.

The total investment in the fisheries was $\$ 22,038,485$, of which Western Alaska furnished more than one-half. The only fishing vessels (for herring and halibut) are those in Southeast Alaskia. An important feature is the large number of transporting vessels-185with a tonnage of 67,109 and a value of $\$ 3,112,307$. Nearly all of 
these ressels are employed in the salmon industry. In number gill nets lead the other forms of apparatus, but are not so eflective as the traps.

In variety of products secured, Southeast Alaska leads all the other divisions. This is largely owing to its greater ancessibility and to the fact that its fisheries hitve been worked for a much longer period than the others. The halibut, herring, and trout fisheries are confined entirely to this section. The eod fishery proper is confined to Central Alaska, only a few thousand pounds being serured incidentally in Southeast Alaska. Western Alaska leads in the value of salmon canned. The only products given for Aretic Alaska are walrus skins, whalebone, walrus ivory, and a whale's head and skull, the latter being a natural-history specimen. Owing to the inaecessibility of the greater part of Western and Aretic Alaskat, practically nothing is done during the winter and early spring months, but as soon is the ice breaks up in the spring the trading vessels muke their romds of the native villages and camps and collect the skins and furs which the natives have taken during the winter and ship these to Pacific coast ports. On account of this method of handling the business, the fiscal year is the better way of showing the year's eatch in this section, ats one whole season thus appears, and not parts of two seasons, which would be the ease were the calendar year shown. It was found an impossibility to secure anything like aceurate data as to the persons employed or the investment in the business of hunting aquatic animals, as it is prosecuted in conjunction with that for land animals, such as bear, marten, mink, lynx, etc., and seems to be general among the natives. Neither has anything been shown of the fishermen and investment in the Aret ic region, owing to the impossibility of securing even approximate data on such matters. The natives keep no records, and besides are in many instances migratory in their habits, thus making it an impossibility to keep track of them.

The total quantity of products secured amounted to $117,247,398$ pounds, valued at $\$ 7,711,981$. As it was found necessary to show in full the prepared products, the figures given represent dressed and cured weights, and not that of the products as taken from the water. There is a tremendous wastage in the Alaska fisheries, especially in that for salmon, fully one-third of the round weight of the latter fish being thrown away in the process of dressing and packing. Had the round weight for all species been shown in the table the total would have been about $155,000,000$ pounds. The salmon and herring fisheries of Alaska are carried on in a somewhat different manner from that followed in other parts of the country. Owing to the lack of what might be called "resident fishermen" in the district, the camneries and guano factory have to do their own fishing, and in order to accomplish this import the necessary fishermen from the Pacific coast states each season. These men are fur- 
nished with fishing gear, boats, lodging, and food throughout the season, and are paid either a certain sum per thousand for each species of salmon (the price paid varying from place to place) or else straight wages. At the end of each season the men are returned to the point from whence they sailed. On account of this procedure it has been found impossible to secure even approximately correct data as to the cost of the fish as taken from the water for the salmon canneries and the one guano factory, and their products have been shown as marketed. So far as the salted salmon and herring and other species are concerned, the data given is in the same form as shown for other sections of the country in the reports of the Bureau. The tables follow.

Persons Employed in the Alaska Fisheries in 1905.

\begin{tabular}{|c|c|c|c|c|}
\hline How engaged. & $\begin{array}{l}\text { Southeast } \\
\text { Alaska. }\end{array}$ & $\begin{array}{l}\text { Central } \\
\text { Alaska. }\end{array}$ & $\begin{array}{l}\text { Western } \\
\text { Alaska. }\end{array}$ & Total. \\
\hline $\begin{array}{l}\text { Fishermen: } \\
\text { Whites......... } \\
\text { Natives ....... } \\
\text { Japanese...... }\end{array}$ & $\begin{array}{r}543 \\
1,147 \\
9\end{array}$ & $\begin{array}{l}658 \\
129\end{array}$ & $\begin{array}{r}1,470 \\
72\end{array}$ & $\begin{array}{r}2,671 \\
1,348 \\
9\end{array}$ \\
\hline Total ..... & 1,699 & 787 & 1,542 & 4,028 \\
\hline $\begin{array}{l}\text { Shoresmen: } \\
\text { Whites .......... } \\
\text { Natives........ } \\
\text { Chinese........ } \\
\text { Japanese....... } \\
\text { Mexicans....... }\end{array}$ & $\begin{array}{r}457 \\
512 \\
375 \\
208 \\
\cdots\end{array}$ & $\begin{array}{r}329 \\
103 \\
552 \\
208 \\
30\end{array}$ & $\begin{array}{r}902 \\
374 \\
1,591 \\
1,215 \\
\cdots\end{array}$ & $\begin{array}{r}1,688 \\
989 \\
2,518 \\
1,631 \\
30\end{array}$ \\
\hline Total...... & 1,552 & 1,222 & 4,082 & 6,856 \\
\hline $\begin{array}{l}\text { Transporters: } \\
\text { Whites......... } \\
\text { Natives........ }\end{array}$ & $\begin{array}{r}187 \\
10\end{array}$ & 184 & 202 & $\begin{array}{r}573 \\
10\end{array}$ \\
\hline Total............. & 197 & 184 & 202 & 583 \\
\hline Grand total... & 3,448 & 2,193 & 5,826 & 11,467 \\
\hline
\end{tabular}

Apparatus and Capital Engaged jn tie Alaska Fisheries in 1905.

\begin{tabular}{|c|c|c|c|c|c|c|c|c|}
\hline \multirow{2}{*}{ Items. } & \multicolumn{2}{|c|}{$\begin{array}{l}\text { Southeast } \\
\text { Alaska. }\end{array}$} & \multicolumn{2}{|c|}{ Central Alaska. } & \multicolumn{2}{|c|}{ Western Alaska. } & \multicolumn{2}{|c|}{ Total. } \\
\hline & $\begin{array}{l}\text { Num- } \\
\text { ber. }\end{array}$ & Value. & $\begin{array}{l}\text { Num- } \\
\text { ber. }\end{array}$ & Value. & $\begin{array}{l}\text { Num- } \\
\text { ber. }\end{array}$ & Value. & $\begin{array}{l}\text { Num- } \\
\text { ber. }\end{array}$ & Value. \\
\hline Fishing vessels: & & & & & & & & \\
\hline $\begin{array}{l}\text { Steam and other power.. } \\
\text { Tonnage.............. }\end{array}$ & $\begin{array}{r}8 \\
209\end{array}$ & $\$ 49,775$ & & & & ......... & $\begin{array}{r}8 \\
209\end{array}$ & $\$ 49,775$ \\
\hline 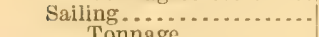 & 8 & 5,550 & & & & & 8 & 5,550 \\
\hline $\begin{array}{l}\text { Tonnage................. } \\
\text { Transporting vessels: }\end{array}$ & 81 & & & & & & 81 & 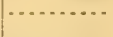 \\
\hline $\begin{array}{c}\text { Steamers and launches.. } \\
\text { Tonnage.............. }\end{array}$ & $\begin{array}{r}59 \\
1,221\end{array}$ & 261,450 & 927 & $\$ 276,300$ & $\begin{array}{r}45 \\
3,616\end{array}$ & $\$ 1,023,357$ & $\begin{array}{r}131 \\
5,758\end{array}$ & $1,561,107$ \\
\hline Sailing .......................... & 10 & 143,200 & & 328,000 & $\begin{array}{r}32 \\
40.688\end{array}$ & $1,080,000$ & 54 & $1,551,200$ \\
\hline 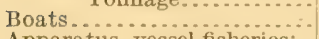 & 794 & 100,685 & 317 & 84,555 & $\begin{array}{r}40,000 \\
928\end{array}$ & 237,782 & $\begin{array}{r}01,031 \\
2,039\end{array}$ & 423,022 \\
\hline $\begin{array}{l}\text { Apparatus, vessel fisheries: } \\
\text { Purse seines . } \\
\text { Lines........................... }\end{array}$ & 6 & $\begin{array}{l}5,000 \\
2,494\end{array}$ & & & & & or & $\begin{array}{l}5,000 \\
2,494\end{array}$ \\
\hline $\begin{array}{l}\text { Apparatus, shore fisheries: } \\
\text { Haul seines............ }\end{array}$ & & & & & & & & \\
\hline 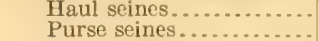 & 57 & 16,075 & 44 & 21,000 & & & 101 & 37,075 \\
\hline Gurse s & $\begin{array}{l}123 \\
197\end{array}$ & $\begin{array}{l}44,950 \\
25,050\end{array}$ & $\begin{array}{r}1 \\
48\end{array}$ & $\begin{array}{l}1,000 \\
2,780\end{array}$ & 909 & & 1,154 & $\begin{array}{l}45,950 \\
85,407\end{array}$ \\
\hline & 32 & 164,000 & 23 & 24,000 & 15 & 19,300 & 70 & 207,300 \\
\hline 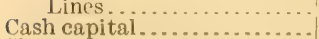 & & $\begin{array}{r}5,381 \\
\end{array}$ & & $\begin{array}{r}10,500 \\
147,144\end{array}$ & & $7,023,506$ & & $\begin{array}{r}15,881 \\
12,013,200\end{array}$ \\
\hline Shore and accessory property & & $1,374,978$ & & $1,756,404$ & & $2,904,142$ & & $\begin{array}{r}12,013,200 \\
6,035,524\end{array}$ \\
\hline Total.. & & $4,041,138$ & .... & $5,651,683$ & & $12,345,664$ & & $22,038,486$ \\
\hline
\end{tabular}


Products of the Alaska Fisheries in 1905.

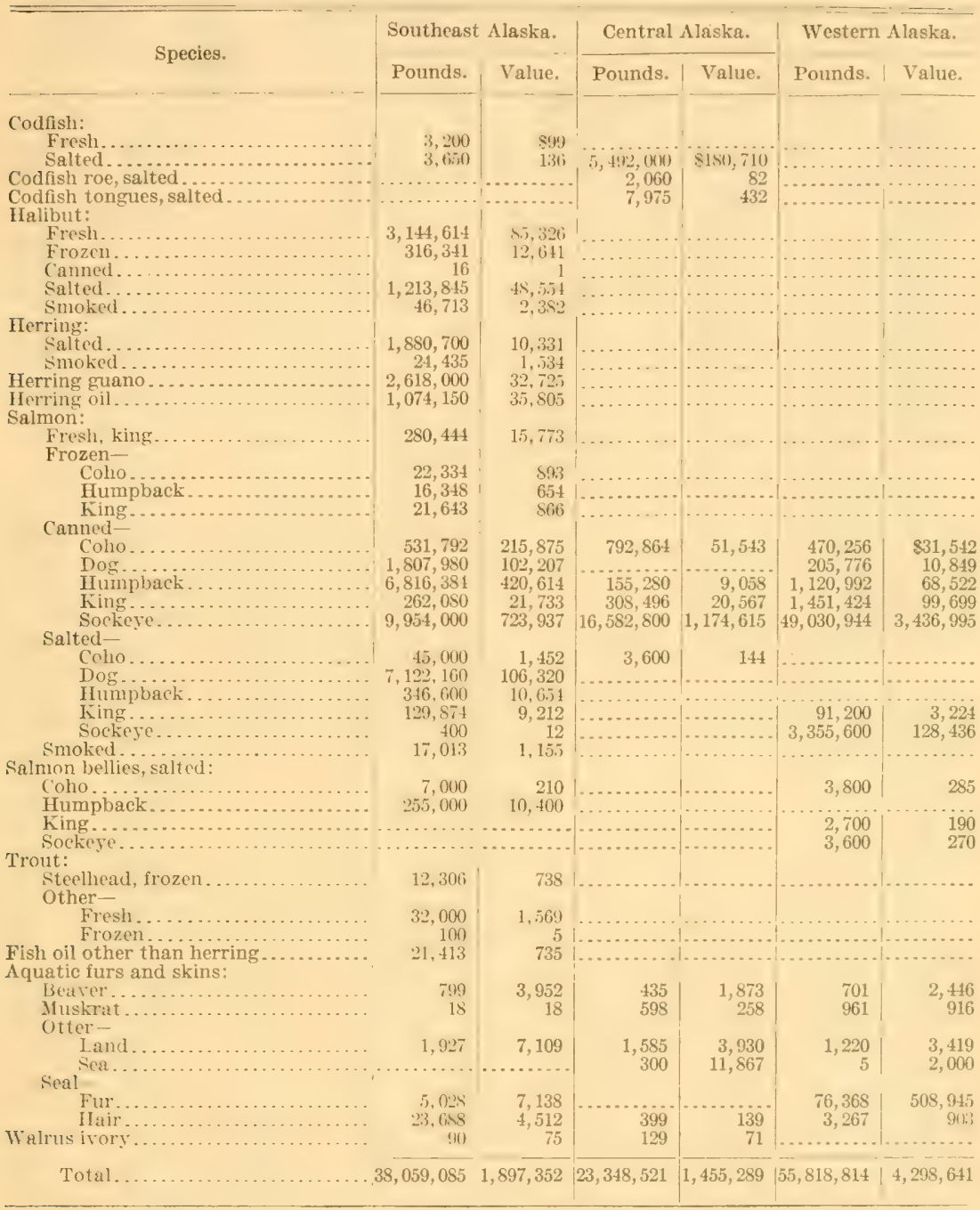


Products of the Alaska Fisheries in 1905-Continued.

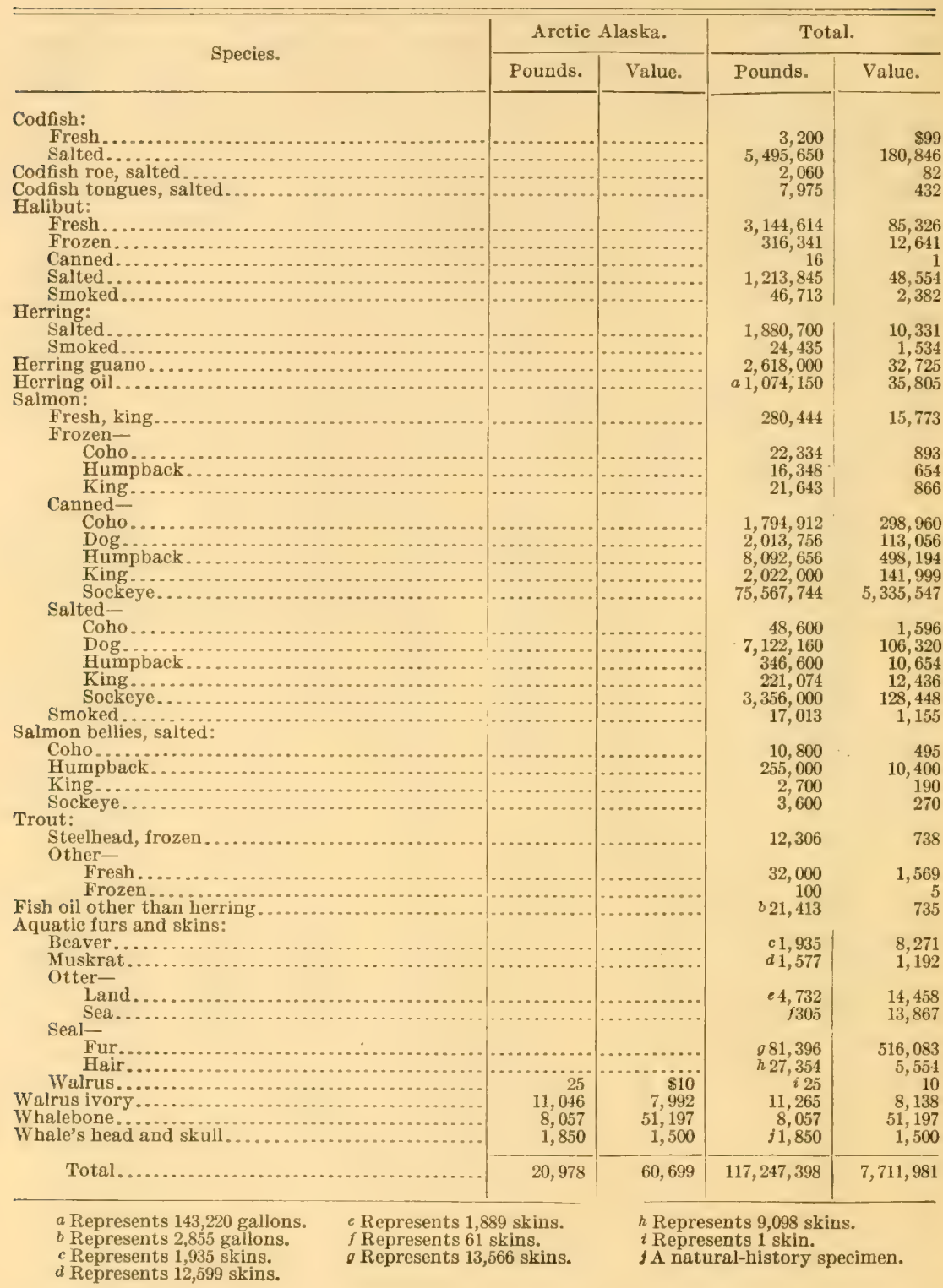


The following table shows in greater detail than the preceding the number of cases (together with the size and style of cans) of each species of salmon canned, and the value of same:

Output of Salmon from Alaska Canneries in 1905.

\begin{tabular}{|c|c|c|c|c|c|c|c|c|}
\hline \multirow{2}{*}{ Species. } & \multicolumn{2}{|c|}{ Southeast Alaska. } & \multicolumn{2}{|c|}{ Central Alaska. } & \multicolumn{2}{|c|}{ Western Alaska. } & \multicolumn{2}{|c|}{ Total. } \\
\hline & Cases. & Value. & Cases. & Value. & Cases. & Value. & Cases. & Value. \\
\hline $\begin{array}{l}\text { Coho: } \\
\quad \frac{1}{2} \text { pound, flat.... } \\
\quad 1 \text { pound, flat.... } \\
1 \text { pound, tall... }\end{array}$ & $\begin{array}{r}516 \\
394 \\
40,169\end{array}$ & $\begin{array}{r}\$ 1,754 \\
1,340 \\
129,696\end{array}$ & 16,518 & $\$ 51,543$ & $\ddot{9}, 797^{-}$ & $\$ 31,542$ & $\begin{array}{r}516 \\
391 \\
66,481\end{array}$ & $\begin{array}{r}\$ 1,754 \\
1,340 \\
212,781\end{array}$ \\
\hline Total.......... & 41,079 & 132,790 & 16,518 & 51,543 & 9,797 & 31,542 & 67,394 & 215,875 \\
\hline $\begin{array}{l}\text { Dog, or ehum: } 1 \\
\text { pound, tall ......... } \\
\text { Humpback: } 1 \text { pound, } \\
\text { tall................ }\end{array}$ & $\begin{array}{r}37,685 \\
142,008 \\
\end{array}$ & $\begin{array}{l}102,207 \\
420,614 \\
\end{array}$ & 3,235 & 9,058 & 23,354 & $\begin{array}{l}10,849 \\
68,522 \\
\end{array}$ & $\begin{array}{r}41,972 \\
168,597 \\
\end{array}$ & $\begin{array}{l}113,056 \\
498,194 \\
\end{array}$ \\
\hline $\begin{array}{l}\text { King: } \\
1 \text { pound, flat.... } \\
1 \text { pound, tall .... }\end{array}$ & $\begin{array}{l}4,248 \\
1,212 \\
\end{array}$ & $\begin{array}{r}17,585 \\
4,148 \\
\end{array}$ & 6,427 & 20,567 & 30,238 & 99,699 & $\begin{array}{r}4,248 \\
37,877 \\
\end{array}$ & $\begin{array}{r}17,585 \\
124,414 \\
\end{array}$ \\
\hline Total....... & 5,460 & 21,733 & 6,427 & 20,567 & 30,238 & 99,699 & 42,125 & 141,999 \\
\hline $\begin{array}{l}\text { Sockeye: } \\
\frac{1}{2} \text { pound, flat.... } \\
1 \text { pound, flat.... } \\
1 \text { pound, tall... }\end{array}$ & $\begin{array}{r}12,915 \\
18,725 \\
175,735 \\
\end{array}$ & $\begin{array}{r}46,674 \\
67,410 \\
609,853 \\
\end{array}$ & 345,575 & $1,174,615$ & $1,021,478$ & $\mid \begin{array}{l}\ldots, \ldots \ldots \\
3,436,995\end{array}$ & $\begin{array}{r}12,915 \\
18,725 \\
1,542,788 \\
\end{array}$ & $\begin{array}{r}46,674 \\
67,410 \\
5,221,463 \\
\end{array}$ \\
\hline Total.............. & 207,375 & 723,937 & 345,575 & $1,174,615$ & $1,021,478$ & $3,436,995$ & $1,574,428$ & $5,335,547$ \\
\hline Grand total.... & 433,607 & $1,401,281$ & 371,755 & $1,255,783$ & $1,089,154$ & $3,647,607$ & $1,894,516$ & $6,304,671$ \\
\hline
\end{tabular}

\section{OTHER FISHERY RESOURCES OF ALASKA.}

By no means are all of the fishery resources of the district utilized even yet. The lakes, streams, and coastal waters teem with the steelhead, Dolly Varden, cutthroat, rainbow, and lake trouts, but the steelhead is the only one shipped, a small quantity being frozen each season. The lake trout (Cristivomer namaycush) is abundant in the Yukon Rirer, and large quantities are caught and sold fresh in the mining towns along the river. Other fresh-water species are the common pike (Esox lucius); the arctic grayling (Thymallus signifer); seven species of white-fish (Coregonus), nearly all of which are important articles of food to the natives living along the rivers entering Bering Sea and the Aretic Ocean, who generally catch them with gill nets set under the ice and in traps; the inconnu (Stenodus mackenzii), which attains a length of 5 feet and a weight of 50 pounds; smelt (Hypomesus otidus), which are very abundant and used as food both fresh and dried; burbot or losh (Lota maculatus): sucker (('utostomus longirostris), and the lamprey (Ammocotus aureus), of which a rast quantity is captured through the ice on the Yukon River each season by the natives and frozen for future use. The eulachon, or candlefish (Thaleichthys pacificus), is one of the best known of the anadromus species, but appears to be abundant in Alaskan rivers only at 
infrequent periods. It has been reported at times as occurring in great abundance in the Stikine, Unuk, and Chilkat rivers, and in the rivers entering into Cook Inlet. It is much prized by the natives because of its oiliness.

In the (for Alaska) densely populated delta between the mouths of the Kuskoquim and Yukon rivers a small black-fish (Dallia pectoralis) is exceedingly abundant and forms the principal food of the natives during the winter months. This fish does not exceed 5 or 6 inches in length, but is very fat, and, in addition to using it whole as food, the natives try out from it a pellucid oil of which they are excessively fond.

Among the sea fishes not described elsewhere in this report and at present of commercial importance to the natives along shore or to the whites living in the vicinity of the fisheries are the following:

Atki mackerel (Pleurogrammus monopterygius), which are not mackerel at all, merely resembling them in flavor, are quite abundant along the southern shore of the Aleutian chain, especially around the island of Attu. They run from May to December, being most plentiful in June, July, and August, and are found in greatest abundance among the kelp in from 3 to 40 fathoms. They retire to deep water in the winter. In length the fish average about 18 inches, with an average weight of about $2 \frac{1}{3}$ pounds. They are an important article of food to the Aleutiuns, who also salt a few barrels annually which they sell to vessels calling at Dutch Harbor and Unalaska. The North American Commercial Company has experimented with these fish for some years and reports them as good food fish. In 1903 the Alaska Attu Mackerel Company was formed at Seattle, Wash., to engage in fishing for and curing this species, and during the same year put up 400 half barrels as an experiment. There is no record of any subsequent operations of the company. The fishery will doubtless be a very important one some day.

Black cod (Anoplopoma fimbria) and the cultus cod (Ophiodon elongatus) are very common in Southeastern Alaska and the Gulf of Alaska, and are excellent food fishes. The well-known redfish of Sitka (Sebastodes melanops) is one of several other species of rockfish found in Alaskan waters, and is exceedingly abundant in the Gulf of Alaska. Flounders seem to be abundant nearly everywhere. Sculpins, capelin, and lance, or lant, are exceedingly :.bundant along the shore and make excellent bait for the better species.

Along the shores of Norton Sound occurs the tomeod (Microgadus proximus), or wachna of the natives. This fish, which is very abundant in the fall and spring, is of immense importance to the natives, as they depend quite largely upon it for their winter's supply of food. 
At first it is caught from boats anchored close to the shore, but when the new ice becomes strong enough to hold them the natives erect stakes with mats hung between to keep of the wind, and fish through holes cut in the ice. The fish are allowed to freeze, and in that condition are stored away in suitable receptacles until needed. They also form an important article of dog feed.

Throughout Southeastern Alaska clams are quite abundant. In 1898 and 1899 the North Pacific Trading and Packing Company packed each year several hundred cases of clams and clam juice, but then abandoned the business for some unknown reason. The clams were packed in September, usually, as they were then in the best condition. In 1903 the Alaska Packing and Navigation Company built a small cannery at Wrangell and put up about 20 cases that same year, but owing to lack of capital the cannery has not been operated since. In 1904, 42 cases were put up by the Alaska Fish and Halibut Company on Wrangell Narrows. There is an excellent opening in this line for experienced persons with a moderate amount of capital.

Along the Alaska peninsula and the Aleutian chain mussels, crabs, and shrimps are very abundant, and squid, octopus, and bêche-demer are quite numerous. All of these are at present utilized as food by the natives and a few of the whites, and large quantities are used as bait in the other fisheries. It is probable that when shipping facilities become better a trade in these products with Puget Sound ports can be built up. The natives also gather certain varieties of algæ and, after drying them, store them away to be eaten in winter.

\section{FISHERIES CARRIED ON IN ALASKAN WATERS AND CREDITED TO PLACES OUTSIDE OF THE DISTRICT.}

Cod.-In addition to the cod fisheries carried on from the shore stations there is a fleet of vessels which operate on the Alaskan banks, but as they hail from ports outside of Alaska they can not be credited to the district. The table below gives full data in regard to the operations of these vessels during 1905. Their methods of work, etc., have already been described in full elsewhere in this report.

Cod Fishing Conduoted in Alaskan Waters in 1905 by Vessef.s from (Ottside PoRTs.

\begin{tabular}{|c|c|c|c|c|c|c|c|}
\hline \multirow{2}{*}{ Home port. } & \multicolumn{4}{|c|}{ Vessels. } & \multirow{2}{*}{ Lines. } & \multicolumn{2}{|c|}{ Salted codfish. } \\
\hline & $\begin{array}{c}\text { Num- } \\
\text { ber. }\end{array}$ & $\begin{array}{l}\text { Ton- } \\
\text { nage. }\end{array}$ & Value. & Crew. & & Pounds. & Value. \\
\hline 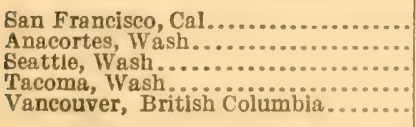 & $\begin{array}{l}6 \\
4 \\
4 \\
1 \\
1\end{array}$ & $\begin{array}{r}1,382 \\
849 \\
422 \\
195 \\
\cdots \\
\end{array}$ & $\begin{array}{r}\$ 88,380 \\
46,096 \\
31,552 \\
8,512 \\
8,512 \\
\end{array}$ & $\begin{array}{r}201 \\
93 \\
70 \\
24 \\
24 \\
\end{array}$ & $\begin{array}{r}\$ 1,260 \\
4,600 \\
950 \\
1,200 \\
1,200\end{array}$ & $\begin{array}{r}2,800,000 \\
2,528,000 \\
948,000 \\
240,000 \\
312,000\end{array}$ & $\begin{array}{r}\$ 85,460 \\
76,904 \\
28,694 \\
7,320 \\
9,516\end{array}$ \\
\hline Total...................... & 16 & 2,848 & 183,052 & 412 & 9,210 & $6,828,000$ & 207,894 \\
\hline
\end{tabular}


Halibut.-The above remarks on the codfish fleet from ports outside of Alaska apply equally well to the Puget Sound fleet operating in the waters of Southeast Alaska for halibut. Full information in regard to this fleet is given elsewhere in this report. The table below shows the number of vessels engaged in the fishery and the catch, together with all other necessary data. The catch of the sail and auxiliary power vessels in Alaskan waters has been taken from the customhouse records at Juneau, but the catch of the steamers had to be estimated, as these vessels return to their home port with their catch and lump the catch taken in Alaskan waters with that obtained outside.

Halibut Fisming Conducted in Alaskan Waters in 1905 by Vessels from Outside PORTS.

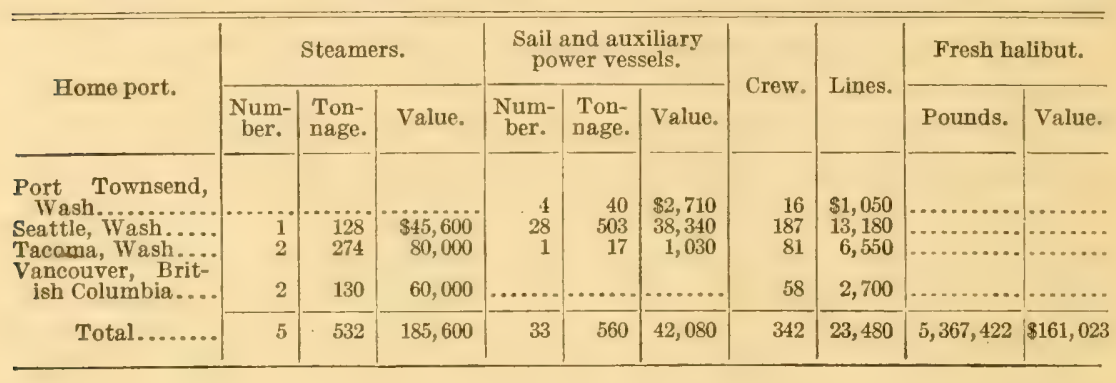






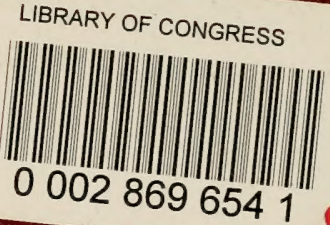

